\title{
Genetic Improvement of Grapevine: Tailoring Grape Varieties for The Third Millennium - A Review
}

\author{
M.A. Vivier and I.S. Pretorius \\ Institute for Wine Biotechnology and Department of Viticulture \& Oenology, University of Stellenbosch, Private Bag X1, 7602 \\ Matieland (Stellenbosch), South Africa
}

Submitted for publication: July 2000

Accepted for publication: August 2000

Key words: Vitis vinifera, genetic improvement, recombinant DNA technology

\begin{abstract}
The remarkable propagative aptitute of grapevine is one of the key factors contributing to its success as a cultivated species and to the spread of the domesticated grapevine, establishing it as one of the most important fruit species worldwide. Today there are some 8 million hectares of vineyards across the world. It is therefore fitting that the successful implementation of the powerful technology of gene manipulation in grapevine is to a large extent reliant on this regenerative ability. Currently, several varieties of grapevines have been successfully genetically transformed, largely by employing somatic embryogenesis to generate highly regenerative target material. Especially attractive in the wine industry is the possibility of improving grapevine varieties by the addition of genes that confer useful traits, such as resistances against biotic and abiotic factors and manipulation of certain metabolic functions. In principle, gene transfer technology allows for the directed manipulation of a specific trait without altering the characteristic nature of the cultivar, permitting the improvement of the traditional cultivars while maintaining their established varietal characteristics. For the most part, targeted traits currently include disease resistance and improved berry quality. The promise of this technology is threatened by worldwide resistance to genetically modified organisms, and in the wine industry by complications surrounding the property rights and naming of transgenic vines. If it is not possible to maintain the varietal name when a transgenic vine has the same properties as the original well known variety, the significant advantages of gene technology over traditional breeding programmes are to a large extent lost. If these and other complications can be overcome, the integration of this powerful technology with traditional breeding programmes, and with other initiatives such as the study of the grapevine genome, will ensure a new era in the cultivation of this ancient species.
\end{abstract}

\section{INTRODUCTION}

The grapevine is as old as time and due to its remarkable regenerative properties has become known as a symbol of life, frequently referred to as the tree of life. Wine, its major product, has been reported in the oldest of historical chronicles and writings. Desirable traits in vines have been identified through the ages as critical discriminatory factors in the making of a superior wine. Once such a wine and its style has found favour with winemakers and consumers, winemakers and grape growers would resist improvements to the cultivar through breeding and/or cultivation practices if it is perceived that these desirable traits would be threatened. Frequently, these traits are polygenically inherited and under the control of groups of genes of minor effect (Mullins et al., 1992), complicating traditional breeding programmes. The demand of the grapevine industries to preserve the desirable characteristics of certain cultivars while generating improved yield, disease and pest resistance, etc. in plant material accentuates the shortcomings of traditional breeding programmes (Robinson et al., 1999).

The last century has witnessed several milestones in agricultural improvements, most notably the post-World War II Green Revolution that caused explosive growth in the sustainable yield of agriculturally important crops. Exhaustive breeding programmes often spearheaded initiatives to maximise the yield on available resources and together with, for example, agrochemi- cals, revolutionised the way crops were cultivated. These programmes raised agriculture to new levels, but to significantly improve on these efforts and to alleviate the negative effect of agriculture on the environment, new initiatives and approaches are needed.

In the biological and agricultural sciences, the ability to genetically manipulate species through recombinant DNA technology, as well as the extensive drive to characterise the genomes of agricultural important species through genomics, initiated the New Green Revolution, that has already had a great impact in several agricultural sectors. The grapevine industries stand to benefit significantly from this technology and much progress has already been made in establishing the groundwork that will lead to a new era in grapevine cultivation. The aim of this review is to provide a perspective on the usefulness of genetic improvement of grapevine, to note what has been accomplished thus far, and to establish what potential this and related technologies hold for the future. To put the new technology and its future application in viticulture in perspective, it is imperative to touch on the origins, classification and characteristic features of grapevines as currently understood. The processes, specific problems and challenges linked to grapevine biotechnology, together with the importance of integrating classical and new technologies, are also discussed. 


\section{GRAPE SPECIES AND VARIETIES}

\section{The genus Vitis}

Grapevines are classified in the genus Vitis, which together with 11 to 13 other genera form part of the Vitaceae family that typically occurs tropically and sub-tropically and exhibits a climbing habit (Pongrácz, 1978). The genus Vitis, however, occurs mainly in temperate climates and consists of two sub-genera, Euvitis and Muscadinia. The former comprises most of the species associated with the genus Vitis; only three species are grouped in the subgenus Muscadinia: $M$. rotundifolia, $M$. munsoiana and $M$. popenoei. (Mullins et al., 1992) (Fig. 1). The species of the two subgenera are quite distinct: some of the most notable characteristics of Euvitis are a shedding bark, small lenticels, branched tendrils, elongated flower clusters and pear-shaped seeds. Muscadinia spp. in contrast, exhibit a non-shedding bark, large lenticels, unbranched tendrils, small flower clusters and boat-shaped seeds (Bailey, 1933; Rives, 1975; Olien, 1990).

The observed phenotypic differences in the two sub-genera of Vitis are confirmed by differences in chromosome composition. Euvitis spp. typically have 38 chromosomes, whereas Muscadinia spp. have 40 (Antcliff, 1992; Mullins et al., 1992; Jackson, 1994). Crosses between these two sub-genera are feasible, but the resulting progeny typically has poor fertility, probably due to imprecise meiotic pairing and separation of the chromosomes. Species within each sub-genus, however, hybridise readily to form vigorous and fertile progeny, a trait extensively used by breeders.

\section{Vitis species}

The classification of Vitis spp. using the criteria usually employed to define a biological species, is often confounded by characteristics such as cross-fertility, similar chromosome numbers and overlapping geographical distributions (Jackson, 1994). It has been suggested that Vitis spp. are still evolving into distinct species and should rather be considered as ecospecies, representing populations of grapevines that are the result of a series of adaptations to specific environmental conditions (Mullins et al., 1992; Jackson, 1994). It has been shown that the quantitative differences observed among species are typically strongly influenced by environmental conditions, and as such are not reliable taxonomic descriptors. Variation within Vitis spp. could possibly best be established on the genetic level, and new technologies of genome analysis will most definitely aid the taxonomic classification of these species (see later sections).

Ancestral Vitis spp.: It is suspected that the ancestral forms of Vitis were bushy plants that preferred sunny locations, and only later developed a climbing habit when the vegetation changed and forestation occurred. To maintain its exposure to sunlight, the ancestral Vitis developed characteristic tendrils that allowed it to improve its climbing ability (Jackson, 1994). The evolution, geographical origins and spread of Vitis spp. have been actively investigated, but remain inconclusive. Whatever the cause and circumstance, a single Vitis sp., V. vinifera, is found in Europe, whereas more than 30 species have been found in China and approximately 34 species have been characterised in North and Central America (Rogers \& Rogers, 1978; Fengqin et al., 1990). It seems that the formation of the continents as we know them today caused a natural distinction in the characteristics of the Vitis spp. that were grouped together with the separation of the landmasses during the Quaternary period (Mullins et al., 1992). The $V$. vinifera spp. are by far the most cultivated of the species, either in pure or in hybrid form and will be discussed in more detail.

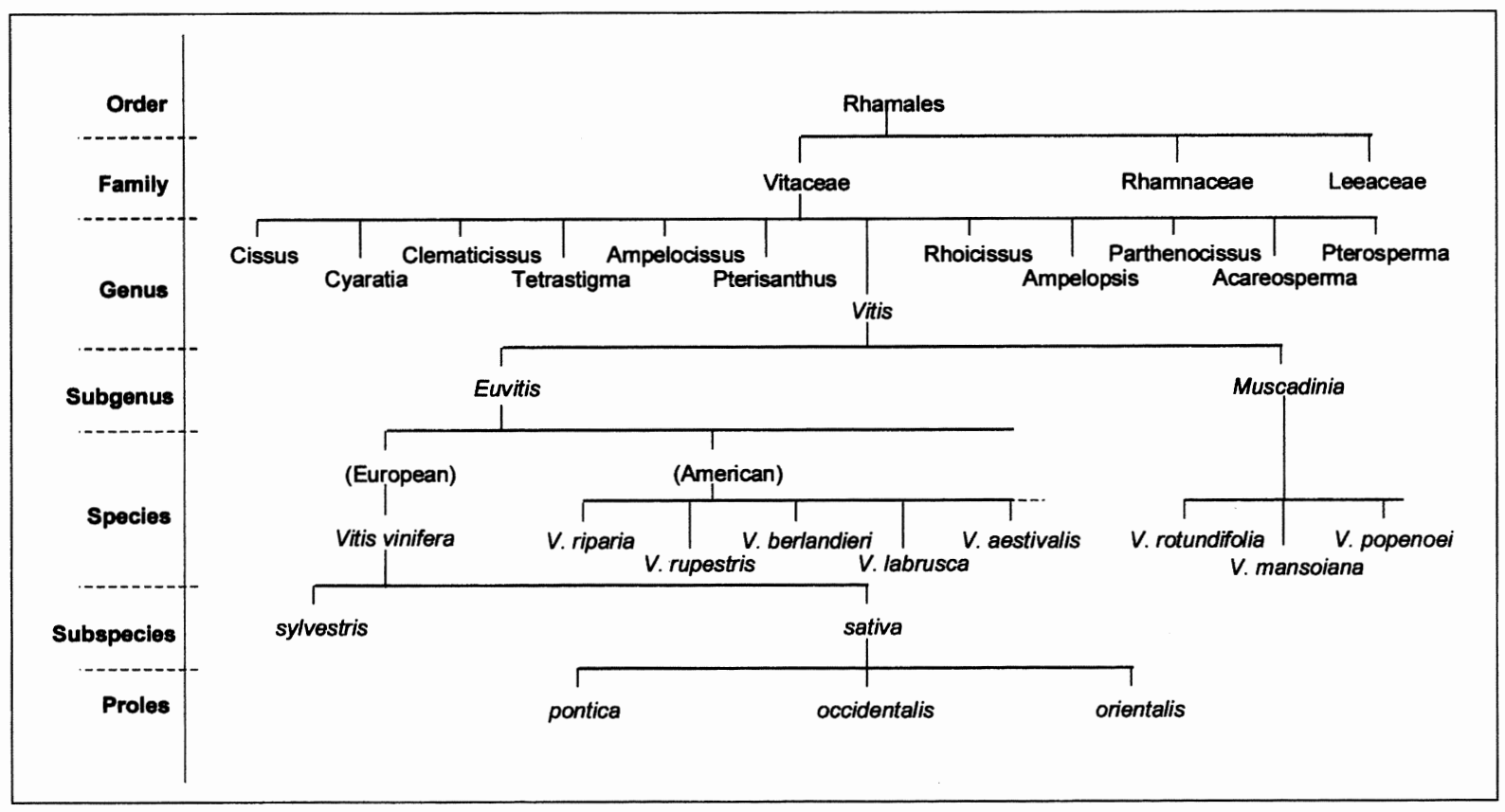

FIGURE 1

Condensed classification scheme of Vitis vinifera (adapted from Mullins et al., 1992). 
Vitis spp. other than $V$. vinifera: The Vitis spp. from Asia have not been extensively studied; slightly more information is available on the North American species. The most well-known American spp. include $V$. labrusca, $V$. aestivales, $V$. riparia, $V$. rupestris, V. Berlandieri and $V$. cinerea. Characteristically, these species have small berries with excessive seeds and strong pungent flavours (Antcliff, 1992). Potentially, they could be very valuable as hybrids with $V$. vinifera, especially due to their strong resistance against certain biotic and abiotic factors. Unfortunately, the exploitation of these gene pools has not been realised in breeding programmes with $V$. vinifera due to several complicating factors such as the extensive backcrosses needed to eliminate some unfavourable characteristics of the American spp. On the other hand, hybrids originating from crosses between the various American spp. have proven to be very valuable as rootstock material, and form the bulk of the rootstocks used today.

Vitis vinifera: Most of the cultivated grapevine species belong to the European grape $V$. vinifera and, together with the important rootstock varieties, comprise the majority of the genetic material used in most viticultural countries (Antcliff, 1992).

The domestication and spread of $V$. vinifera: The domestication of $V$. vinifera probably occurred as early as 5000 BC in Europe, based on the presence of semi-wild seed in areas associated with human activities. A distinction is sometimes made between wild vines of $V$. vinifera, designated subspecies sylvestris, and domesticated species, designated subspecies sativa. Some believe that this distinction between wild and cultivated is merely domestication, and that the wild vines are just the spontaneous forms of the cultivated vines. The seeds and pollen of wild vines are, however, distinguishable from those of domesticated vines and form the basis of interpreting fossilised remains (Jackson, 1994).

Unlike many other crop plants, domestication occurred with relative ease in grapevine. Several attributes of grapevines, such as the natural ability to climb, made it possible to cultivate it together with other crops with minimal attention. Also, due to its minimal requirements for minerals and water, it could survive and grow well in shallow and marginal soils unsuitable for other crops. Another attribute of grapevine that ensured its success as a domesticated crop plant is its impressive propagative aptitude, making it easily propagated, but also allowing it to be intensely pruned, causing the trailing climber to become a short, shrublike plant suitable for monoculture (Jackson, 1994). Perhaps the most significant adaptation that occurred in the domestication of $V$. vinifera is the change to functional bisexuality (Carbonneau, 1983). Typically, wild vines are functionally unisexual and the shift to self-fertile flowers significantly improved the prospects of the vine as a successful crop plant (Mullins et al., 1992). Other distinctive features characteristic of domesticated grapes are a significantly lower seed index and larger berry size.

Grape production and winemaking have always been linked, and the role of wine in religious ceremonies provided a powerful driving force for the cultivation of grapes and the subsequent spread of viticulture. It is generally accepted that winemaking had its origins in southern Caucasia, in an area currently represented by parts of northwestern Turkey, northern Iraq, Azerbaijan and Georgia (Jackson, 1994). It is also suspected that $V$. vinifera were domesticated in this area, with a possible independent domestication in Spain as well (Stevenson, 1985; Núñez \&
Walker, 1989). From these areas the domesticated grape systematically spread to the areas that we currently recognise as cultivation regions (Fig. 2). It is generally accepted that domesticated vinifera grapes were carried westward along with human migration patterns, and resulted in the establishment of wine production in the Mediterranean. Historical records also indicate that vines spread to other parts of the world not indigenous for Vitis, such as Palestine, Italy, France, Spain, Germany, Africa and Australia, due to colonisation. Today there are approximately 8 million hectares of vineyards across the world.

The cultivars that were domesticated earlier, and therefore subjected to selection for a longer period, are likely to display more recessive traits linked to domestication, such as bigger, juicier berries and large branched grape clusters, than cultivars with a more recent origin. This forms the basis of the three proles cultivar-grouping system of Negrul (1938), in which proles orientalis, proles pontica and proles occidentalis are identified, with the former being the oldest and the latter the most recent in evolutionary origin. The orientalis group is found mainly in Central Asia, Afghanistan, Iran, Armenia and Azerbaijan, and consists mostly of table grape varieties, whereas the pontica group is situated in Georgia, Asia Minor, Greece, Bulgaria, Hungary and Romania and consists mostly of wine grapes with a few table grape varieties. The cultivars present in France, Germany, Spain and Portugal are of relatively "recent" origin, closely resemble wild vines and are placed in the occidentalis group, which comprises mostly wine grapes (Negrul, 1938; Pongrácz, 1978). These groupings are sometimes further refined to "sortotypes"; to group varieties that share a geographic origin and a number of morphological and agronomic descriptors (Negrul, 1938).

Nomenclature describing grapevine cultivars and clones: In the wine industry, the quality of a wine is frequently linked to a specific well-established varietal name. To this end, and especially for the discussion of transgenic cultivars, it is important to define the use of the words variety and clone in viticultural terms. As referenced by Walter (2000), Boursiquot defined it as follows: "the variety is the product of a single seed or individual, multiplied by vegetative reproduction. During the reproductive cycles, variations may appear and the variety is made up of a set of clones that retain the same name (hence clonal selection) as long as their phenotype is largely similar. When the variation modifies an obvious character or a character with major technological consequences, the clone is said to be a differentiated form of the initial variety." An example of the different levels of classification of $V$. vinifera is shown in Table 1 .

The word cultivar is a combination of the terms cultivated and variety and should be distinguished from the analogous botanical variety, which is a population of plants with unique characteristics that occur naturally. It is important to note that although a cultivar is also a unique population of plants, it is artificially maintained by human effort and would probably not thrive otherwise (Hartmann et al., 1990).

Cultivar Origins: Despite the relatively "early" domestication of grapevine, the scientific record of the origin of cultivars is unfortunately not significantly comprehensive. After the late nineteenth century more information is available on cultivar origins, but the earlier records are still rather fragmentary. 


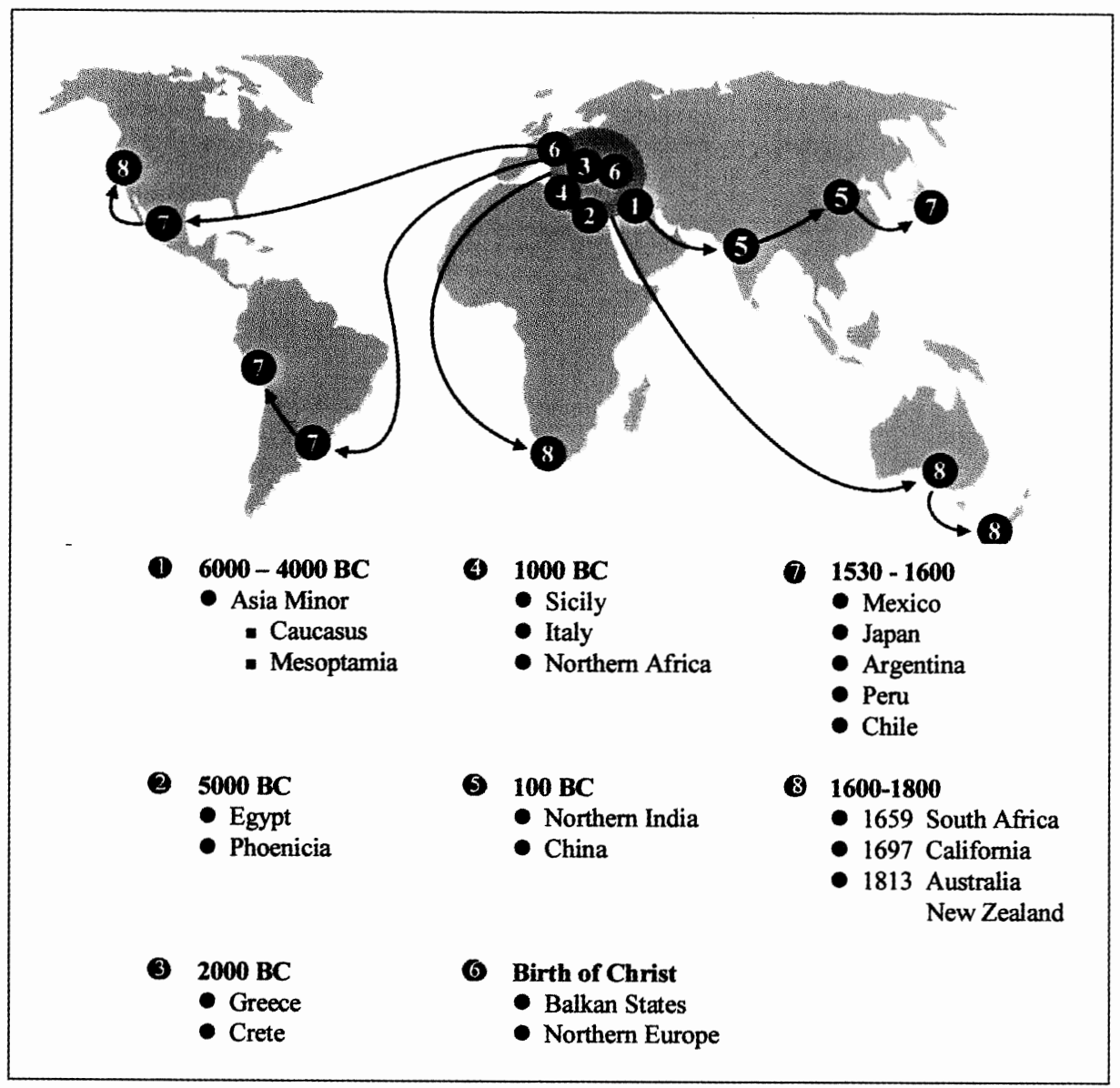

FIGURE 2

The distribution and spread of vines and wine-making through the ages (from Pretorius, 2000).

\section{TABLE 1}

The different levels of classification of Vitis vinifera (Walter, 2000).

\begin{tabular}{ll}
\hline \multicolumn{1}{c}{ Classification level } & Example \\
\hline Species & V. vinifera \\
Sub-species & sativa, sylvestris \\
Proles & occidentalis, pontica, orientalis \\
Families/sortotypes & noiriens, carmenets \\
Varieties & Pinot, Grenache, Traminer etc. \\
Sub-varieties & Pinot noir, Pinot blanc, Pinot gris etc. \\
Clones & Clone numbers 112, 114, 115 etc. \\
\hline
\end{tabular}

Ampelography as a classification tool for cultivars: Complicating the tracing of cultivar origins is the fact that morphological comparisons based on ampelographic characteristics are only useful when cultivars were derived from a common ancestor. Some cultivars have, for instance, developed through a specific mutation which introduced a desirable trait maintained through vegetative propagation. In these instances it should be possible to identify origins through ampelographic analyses. To this end, an extensive database of ampelographic characteristics has been compiled for a huge variety of cultivars to aid in the correct identification of cultivars and the study of origins (Silvestroni et al., 1996; Roytchev, 1997; Eibach, 1999).

As seen in the evolution of taxonomy, the classification method of choice at a given point in time reflects available technology levels and insight into the discipline at that point. As technological advances occurred, the shortcomings of ampelography became evident, leading to several technologies being incorporated into the discipline to enhance its usefulness. One of the most promising applications includes the use of artificial neural networks to identify grapevine genotypes based on ampelography (Mancuso et al., 1998). Other computer-based data acquisition methods further improved ampelometrics (Costacurta et al., 1996a).

Chemical and biochemical analysis of cultivars: When a cultivar 
originates from a crossing event, it is highly likely that the morphological characteristics will change from the parents to the progeny. Therefore, ampelography cannot be used to deduce the origin of the cultivar under investigation; classification and identification of grapevines are aided by chemical and biochemical analyses to complement morphological analyses. Among examples are chemotaxonomic classification methods relying on anthocyanin profiles, where varieties are classified according to a few enzymatic indicators involved in anthocyanin biosynthesis. These profiles are supposedly genetically inherited and independent of environmental conditions (Carreño et al., 1997). Combinations of various isoenzymatic activities, such as esterase (EC 3.1.1.1), acid phosphatase (EC 3.1.3.2), phosphoglucomutase (EC 2.7.5.1) and glucose phosphate isomerase (EC 5.3.1.9) were used in combinations with ampelography to correct some errors in existing classification schemes and more accurately measure the distance between cultivars (Walker \& Boursiquot, 1992; Eiras-Dias et al., 1996; Abdallah et al., 1998; Eiras-Dias \& Bruno-Sousa, 1998).

Genetic marker technology in the identification of cultivars: Although valuable, the aforementioned methods all have limitations in establishing the genetic distance between cultivars, rootstocks and clones, due to their reliance on descriptors that can be influenced by the plant's environment and physiological state. Methods that analyse genetic diversity directly at DNA level have proven highly valuable and have advanced grapevine taxonomy significantly. DNA marker technology, including $\underline{R}$ estriction $\underline{F}$ ragment $\underline{L}$ ength $\underline{P}$ olymorphism (RFLP), $\underline{R}$ andom $\underline{A}$ mplified $\underline{P}$ olymorphic $\underline{D}$ NA (RAPD) and $\underline{S}$ equence $\underline{T}$ agged $\underline{S}$ ite (STS), caused a revolution in the classification, identification and study of genetic diversity of grapevine cultivars and rootstocks (Costacurta et al., 1996b; Sensi et al., 1996; This et al., 1996, 1997; Stavrakakis \& Biniari, 1998; Ye et al., 1998; Vidal et al., 1999). The STS microsatellite marker technology is based on the isolation of hypervariable DNA repeat sequences found in the grapevine genome, which are flanked by consistent typical DNA sequences (Thomas et al., 1996). These invariable flanking sequences can be used to define primers for polymerase chain reaction (PCR) amplification of the hypervariable regions, which are then typically used to analyse multiallelic individual genetic loci. This DNA marker type is highly polymorphic and shows a co-dominant mode of inheritance, making it ideal in cultivar identification, parentage determination, population genetics and physical and genetic mapping (Thomas et al. 1994; Regner et al., 1996; Bowers \& Meredith, 1997; Sefc et al., 1997; Grando \& Frisinghelli, 1998; Sefc et al., 1998a, b; Bowers et al., 1999). The co-dominant mode of inheritance of microsatellites also allows for the transfer of markers between maps derived from different crosses (Grando \& Frisinghelli, 1998).

The success of this technique is best demonstrated by recent examples of parentage analyses of some of the most important wine grape cultivars in the world. In an elegant study, Bowers \& Meredith (1997) conclusively showed that the parents of Cabernet Sauvignon were Sauvignon Blanc and Cabernet Franc. It was shown that the parent cultivars are genetically quite dissimilar, since they shared only 12 of 56 alleles at 28 loci studied (Bowers \& Meredith, 1997). In a recent study, where more than 300 grape cultivars were analysed, 16 of the cultivars with a long association to northeastern France were shown to be the progeny of a single pair of parents, namely Pinot (a collective name for Pinot noir, Pinot gris, Pinot blanc and Pinot meunier) and Gouais blanc (Bowers et al., 1999). These results were based on the analysis of 32 microsatellite loci and showed that the progeny probably developed through individual crossing events, giving rise to amongst others, Chardonnay, which can be traced back to the early Middle Ages. It seems possible that these two parents were successful in generating a large progeny because of the significant genetic distance between them (as is the case for the parents of Cabernet Sauvignon) (Bowers \& Meredith, 1997; Bowers et al., 1999). Grapevine is especially intolerant of inbreeding, and information regarding genetic distance might significantly benefit modern grape breeding programmes (Bowers et al., 1999).

A recent application of microsatellite markers is the authentification of $V$. vinifera grape must (Faria et al., 2000). Four microsatellite loci were used to differentiate five of the most important port wine producing cultivars; the DNA banding patterns found for the respective grape cultivar leaves were in agreement with the profiles of the corresponding musts (Faria et al., 2000). With the ever-increasing number of useful microsatellites being described, this useful application may soon be available for authentication of more varietal musts.

The cultivars on which viticulture relies: how to improve on them?: Historical data of cultivar origins and spread, combined with the means to accurately determine the genetic distance between cultivars, will significantly improve our current knowledge of the genetic events that led to the current cultivar range, as well as redress classification errors and double designations (Sefc et al., 1997). Although more than 24000 names are used for cultivars, it is thought that $V$. vinifera only comprise approximately 5000 true cultivars (Alleweldt, 1988). Most of the V. vinifera cultivars currently in existence probably originated through spontaneous crosses between wild vines and cultivars, domestication of wild vines or spontaneous crosses between two cultivars (as is the case for Cabernet Sauvignon) (Levadoux, 1956). Controlled crosses, on the other hand, have yielded very few new commercially viable cultivars. This can be partly attributed to the conservatism of the wine industry regarding new varieties. Also, since the developed progeny receive a new cultivar name, producers and winemakers lose the marketing advantage of the parental cultivars' names (Meredith, 1999). The use of new cultivars is therefore frequently restricted to countries where wine production is less established. In South Africa, Pinotage is a highly successful commercial cultivar originating from a controlled cross between Pinot noir and Cinsaut (Hermitage) that has only recently started to gain recognition and acceptance in the international market.

Some of the earliest deliberate crosses occurred in North America and involved native American Vitis species. Several crosses also occurred between imported $V$. vinifera cultivars, especially $V$. labrusca and to a lesser extent $V$. aestivalis and $V$. rupestris. These cultivars are popularly termed American hybrids to distinguish them from the French hybrids, or direct producers, which were cultivars originating from crosses between $V$. vinifera, $V$. rupestris, $V$. riparia or $V$. lincecumii in France (Antcliff, 1992; Jackson, 1994). The main aim in the establishment of the direct producers was to eliminate the need for grafting and to combine the resistant phenotypes of the 
American cultivars with the vinifera backgrounds. Due to their success, they were considered a threat to the indigenous character of the French wine industry and all new plantings were banned in France, but these cultivars are still widely used in North America and other parts of the world (Jackson, 1994).

The American spp. played an enormous role in controlling the phylloxera epidemics (caused by the root-eating insect Phylloxera vastatrix / Dactylasphaera vitifolia) that devastated the vineyards of several prominent wine- and grape-producing countries. These species co-developed with phylloxera in their natural habitats and therefore gained varying degrees of resistance. They are used, especially in hybrid form with other American spp., to graft the scion cultivars on for protection against phylloxera, nematodes and other adverse abiotic factors.

The reality is that the wine industry relies predominantly on a few select and ancient cultivars, of which several erroneous classifications and designations exist and of which limited reliable parentage and origin records are available. The correct handling, maintenance and improvement of this ancient and invaluable genetic resource is of the utmost importance if the worldwide wine industry wants to stay competitive in the new era of technology, limited resources and environmental pressure.

\section{TECHNOLOGY MEETS AN ANCIENT GENOTYPE IN GENETIC IMPROVEMENT PROGRAMMES USING RECOMBINANT DNA TECHNOLOGY}

\section{Definitions}

The use of genetic manipulation in agriculture is generally seen as the basis of the new era in agricultural advancement and has been labelled the New Green Revolution, or the Evergreen Revolution. In principle this technology involves the ability to transfer genetic material between living organisms without the constraints of genetic incompatibility, species barriers, inbreeding and depression phenomena normally linked to genetic crosses in breeding programmes. In Plant Biotechnology, genetic manipulation generally involves the transfer of the target gene(s) that imparts a specified characteristic to the plant material of choice through a specific transformation protocol, and the subsequent regeneration and analysis of transgenic plantlets.

For the sake of clarity, some of the terminology used in Plant Biotechnology should be defined. Genetic manipulation refers to the processes of genetic improvement through recombinant DNA technology, and not to processes characteristic to traditional crossbreeding programmes. Almost all plants and animals of agricultural importance today are the result of some sort of genetic manipulation through traditional breeding techniques (Meredith, 1999), but these processes will not be discussed here. The term genetic transformation refers to the process through which genes of interest are introduced into the target plant material, usually through a direct/physical process such as biolistic bombardment or a biological process such as Agrobacteriummediated transformation. The reference to a transformed plant as transgenic is the technically correct term for a plant that has received a new or modified gene through transformation. The more general use of genetically modified organism (GMO) is used to describe any living organism that has received a foreign gene through recombinant DNA technology.

\section{Processes in Plant Biotechnology}

Generally, three elements are needed to transfer genes into plants: (i) isolated and characterised genes of interest encoding useful traits; (ii) a reliable and reproducible method to introduce the isolated genes into the cells of the target plant species; and (iii) a system to supply suitable target plant tissue to receive the genetic material of choice and the ability to regenerate transgenic plants from the resultant cells.

The first transgenic plants were generated approximately 20 years ago; since then a wide variety of plant species has been added to the list of successfully transformed species, including crop species such as tomato, potato, lettuce, canola, cotton, soybean, pea, carrot, cabbage, cucumber, strawberry, alfalfa, sweet potato, sunflower, flax, lotus, sugar beet, papaya, kiwi, cranberry, eggplant, pear, apple, grape, asparagus, rye, corn and rice (Fischhoff et al., 1987; Baribault et al., 1989; Delannay et al., 1989; Hemenway et al., 1989; Baribault et al., 1990; Perlak et al., 1990; Potrykus, 1990; Brunke \& Meeusen, 1991; Hill et al., 1991; Lee et al., 1991; Potrykus, 1991; Cheng et al., 1992; Jongedijk et al., 1992; Murphy, 1992). These successes made it clear that huge differences exist between different plant species in terms of transformation and regeneration (Robinson et al., 1999). Woody perennials, such as grapevine, proved to be especially recalcitrant and the first successful transformation events were only reported in 1989 and 1990 (Baribault et al., 1989, 1990) where transformed calli and chimeric shoots were obtained, respectively. The first successful plant regeneration of transformed explants was reported for $V$. rupestris (Mullins et al., 1990). Since then several other successes have been reported, with a wide variety of explant types and transformation and regeneration protocols used (Berres et al., 1992; Hébert et al., 1993; Le Gall et al., 1994; Martinelli \& Mandolino, 1994; Mauro et al., 1995a, b; Perl et al., 1996a, b; Franks et al., 1998). In the following sections the important factors that have been shown to be critical in efficient grapevine transformations are discussed.

\section{Embryogenesis in grapevine: yielding the most suitable target material for genetic manipulation}

Many plant species are capable of inducing embryo formation from proliferating unorganised cells through the process of somatic embryogenesis. This process is strongly regulated by plant hormones such as auxin and is the somatic alternative of zygotic embryogenesis, in which the embryo originates from the fusion between male and female gametes. Somatic embryogenesis typically encompasses two stages, the first being the induction of embryogenic potential of somatic cells through the presence of auxin. This stage is unique to somatic embryogenesis, since an intrinsically embryogenic zygotic embryo does not require the exogenous induction of embryogenic competence (Dodeman et al., 1997).

Apart from the hormonal control of the transition from somatic to embryogenic cells, cell polarity and asymmetric cell division are also key to the process of somatic embryogenic initiation (Dodeman et al., 1997). It is speculated that auxin probably modifies the cell's polarity by moderating the $\mathrm{pH}$ gradients and electrical fields around the cell, leading to the initiation of transition (Dijak et al., 1986; Dodeman et al., 1997). The controlled cell expansion and asymmetric divisions important in the formation 
of embryogenic cells are both linked to the heterogeneous partitioning of cytoplasmic determinants subsequent to the formation of cell polarity (Dodeman et al., 1997).

The induction phase of somatic embryogenesis usually ends with the formation of groups of 10-50 small, dense cytoplasmic cells called proembryogenic masses (PEMs), (Halperin, 1966). The second stage of somatic embryogenesis is generally initiated when PEMs are transferred to an auxin-free medium and subsequently display the characteristic successive stages of embryo development of plants (Fig. 3) (Dodeman et al., 1997). The basic stages of globular, heart-shaped, torpedo and cotyledonary embryo development are evidenced in zygotic and somatic embryogenesis, but the comparisons between the two types can only be established from the globular stage onwards.

Apart from the obvious similarities, there are two main differences between the two types of embryogenic developments, namely the absences of endosperm and a normally functioning suspensor in somatic embryogenesis. The lack of development of a functional suspensor in somatic embryogenesis in tissue culture indicates that the suspensor, although sometimes present, is not important for embryo development, or that the controlled culture conditions render the normal feeding-role of the suspensor obsolete (Dodeman et al., 1997; Modhorst et al., 1997). Unlike their zygotic counterparts, somatic embryos do not become dormant, which explains the absence of endosperm in the latter. Somatic embryos do, however, form storage proteins, albeit at an earlier stage in development and at a lower rate, confirming that the developmental programme for storage protein accumulation is present (Shoemaker et al., 1987). The lack of somatic embryo dependence on the endosperm can again indicate its non-essential status, or functional substitution by the growth media with regards to embryo development. In grapevine, however, the genesis of somatic and zygotic embryos are quite correlated (Altamura et al., 1992; Faure et al., 1996a, b).

Somatic embryo cultures can be linked to many of the reported successful transformations of $V$. vinifera. In principle, it involves a system in which individual somatic cells give rise to embryos that are able to regenerate into new plants, as reported by a number of different research groups working on grapevine (Nakano et al., 1994; Mauro et al., 1995a; Scorza et al., 1995; Perl et al., 1996a, b; Scorza et al., 1996; Franks et al., 1998; Martinelli \& Mandolino, 2000). The highlights of these successes are discussed in the sections below.

Explants used in grapevine somatic embryogenesis: Successful somatic embryogenesis of $V$. vinifera was first reported in an experiment in which unfertilised ovules of Cabernet Sauvignon were cultured in a liquid medium (Mullins \& Srinivasan, 1976; Srinivasan \& Mullins, 1980). Since then several other explant types and genotypes have been successfully subjected to somatic embryogenesis. These include leaf, petiole and stem segments in the interspecific-hybrid Seyval (Krul \& Worley, 1977), petioles and leaves for $V$. vinifera and $V$. rupestris genotypes (Stamp \&

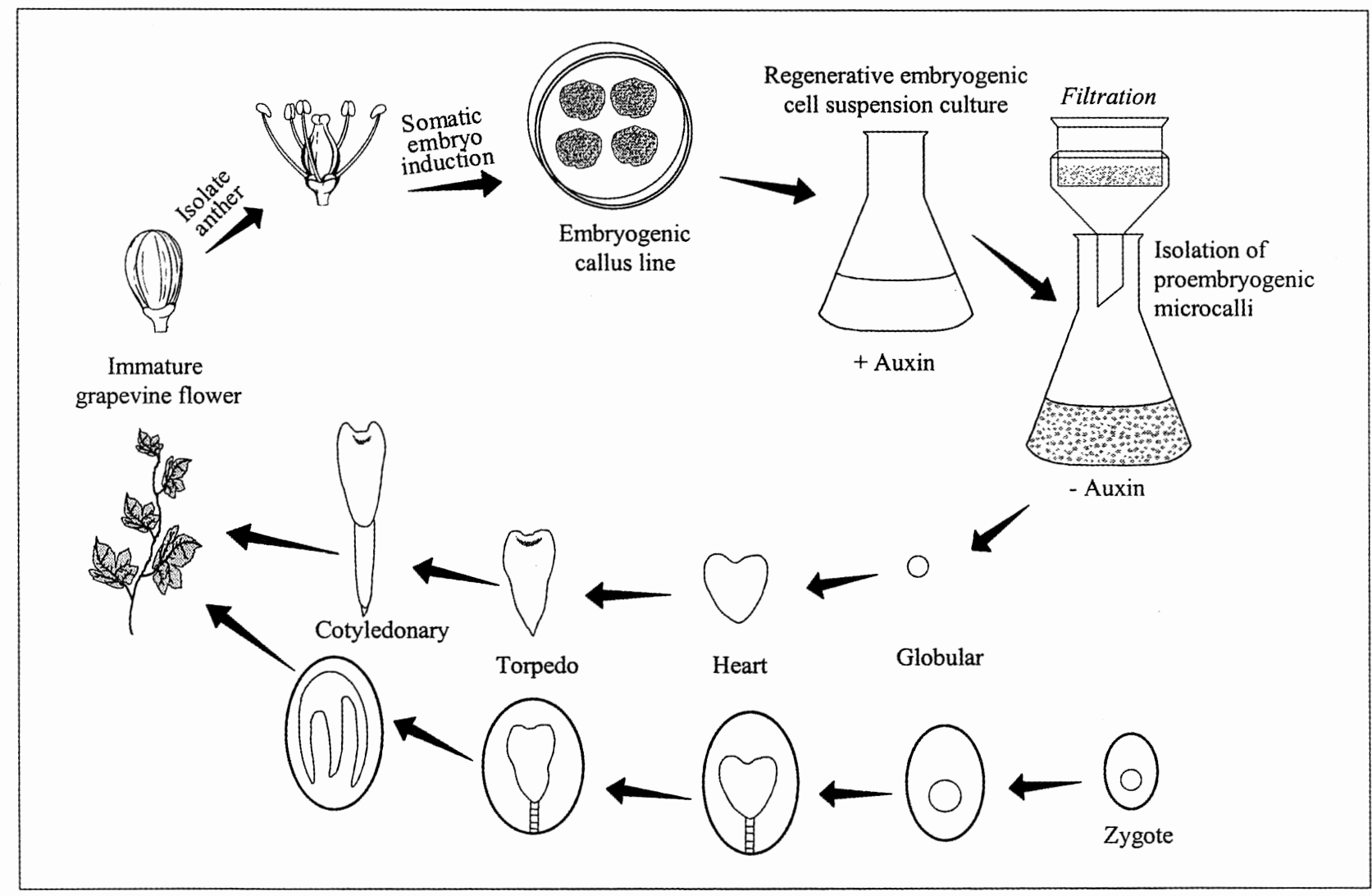

FIGURE 3

Unique and shared features of zygotic and somatic embryogenesis in grapevine (adapted from Dodeman et al., 1997). 
Meredith, 1988a; Martinelli et al., 1993; Nakano et al., 1994; Scorza et al., 1996) and ovules and zygotic embryos for various cultures of $V$. acerifolia and cultivars of $V$. vinifera (Gray \& Mortensen, 1987; Stamp \& Meredith, 1988b).

Anther-derived tissues are undoubtedly the most widely used explant types in generating somatic embryos for various rootstock varieties, cultivars of $V$. vinifera and other hybrids (Rajasekaran \& Mullins, 1979; Bouquet et al., 1982; Rajasekaran \& Mullins, 1983a, b; Mauro et al., 1986; Gray \& Meredith, 1992; Le Gall et al., 1994; Krastanova et al., 1995; Mauro et al., 1995a, b; Perl et al., 1995; Faure et al., 1996a, b; Kikkert et al., 1996; Franks et al., 1998). Somatic embryogenesis from anther tissues seems to be genotype dependent and usually requires extensive optimisation of culture conditions before a suitable induction protocol for a specific genotype is established (Perl \& Eshdat, 1998). Although the rate of initiation of embryogenic cultures is notoriously low, several treatments such as explant chilling, collection of anthers near first pollen mitosis and experimentation with hormone treatments overcame some of the problems (Perl \& Eshdat, 1998). These improvements led to reports such as those of Bouquet (1989), stating that somatic embryos and regenerated plantlets have been obtained for 22 genotypes of $V$. vinifera, four interspecific hybrids and 12 rootstocks.

It seems that the callus tissue with embryogenic potential originates from the anther filament at the site where it attaches to the anther head (Franks et al., 1998). The cultures therefore originate from diploid filament (somatic) tissue and not from haploid anther cells. From histological analysis it was evident that the polarity of the somatic embryo was established at the first division, since the developing embryo was already asymmetric at the bicellular stage, exhibiting a large basal cell and a small apical cell (Faure et al., 1996b). As the apical cell underwent further embryonic cell divisions, it was possible to distinguish between suspensorial and embryonic cells, which became increasingly differentiated during PEM-formation (Faure et al., 1996b).
Description of the most useful cell-line types: Several researchers have stated that the type and quality of the embryogenic cell-lines have a direct positive correlation with the outcome of the genetic transformation. Successful transformation events have been reported from both somatic embryogenic celllines maintained in suspension and on plates. Perl \& Eshdat (1998) concluded that the most useful embryogenic cell-lines comprise two types. The first type described, is arrested through the use of auxin at an early state in the embryogenic development, and the cultures consist of very fine, pre-embryogenic cells. Very high transformation frequencies and selection efficiencies are obtained from these highly regenerative cells. The other cell-line type described, multiplies by secondary embryogenesis from somatic embryos arrested at a more advanced state of development, and has proven to be more difficult to transform, select and regenerate. These cell-lines and slight variations thereof, correspond to the bulk of the suspension cultures successfully used by various other researchers.

Franks et al. (1998), on the other hand, described embryogenic lines maintained on solid medium with which they obtained excellent results in transformation experiments (Fig. 4). These plated cultures were also anther-derived and consisted of either callus which was covered on the surface with globular embryoids (type I), or a culture that frequently originated from type I callus and consisted of somatic embryos at various stages of development (type II). The type I callus was preferred for the transformation experiments and reproducibly yielded significant numbers of transgenic plants, whereas the type II callus yielded few transgenics (Franks et al., 1998; Robinson et al., 1999). This strategy for grape genetic transformation is based on the ability of isolated somatic embryos to produce secondary embryogenesis; this also allowed the definition of an efficient protocol for a stable and no-chimeric insertion of the foreign gene in $V$. rupestris plantlets (Martinelli \& Mandolino, 1996).

The most important prerequisites for a useful cell-line are genetic stability and uniformity. It has been shown that grapevine

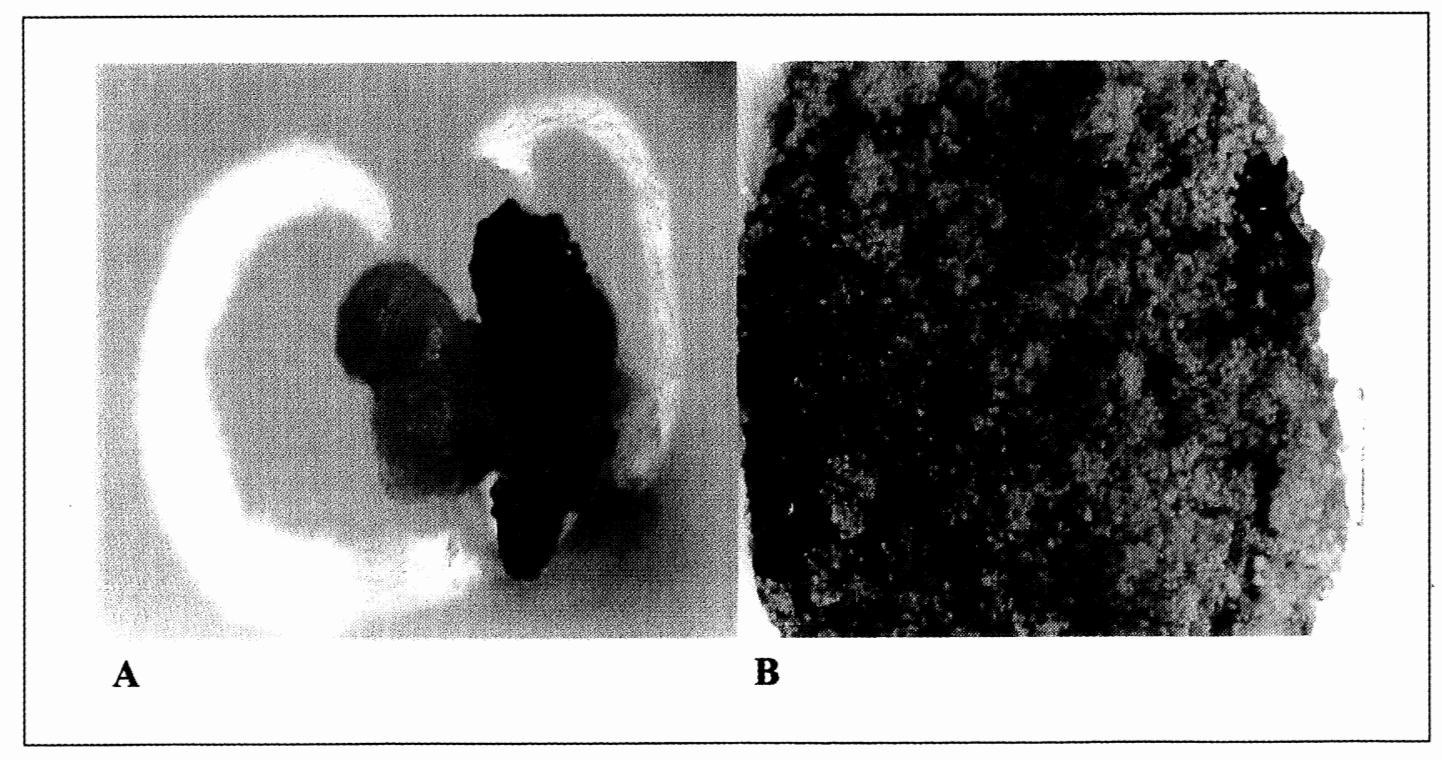

FIGURE 4

Somatic embryogenesis in grapevine. (A) An isolated immature anther on callus induction medium, undergoing callus formation (B) a synchronous cell-line consisting of pre-embryogenic masses. 
somatic embryos are of single cell origin and are therefore genetically uniform (Faure et al., 1996b). In an attempt to investigate the probability of somaclonal variation in somatic embryogenic cultures, the "true-to-typeness" of 87 transformed Sultana individuals, regenerated from somatic embryos, was evaluated by DNA microsatellite analysis at six loci (Franks et al., 1998). The results of these experiments showed that somaclonal genetic changes, somatic meioses and the induction of callus from haploid tissue does not occur or is rare in grapevine cultures (Franks et al., 1998; Robinson et al., 1999). Other important characteristics of useful cell-lines for transformation experiments include the ability to maintain the cultures over long periods without the loss of regenerative ability and efficient selection schemes to eliminate chimeras (Perl \& Eshdat, 1998).

Regeneration of grapevine after somatic embryogenesis: One of the classic problems experienced in the somatic embryogenesis of grapevine was the difficulty in manipulating the development of the embryos to the cotyledonary stage and regenerating normal plantlets from them. Typically, the cultures arrested at the globular or heart-stage of development or produced abnormal embryos and plantlets (Rajasekaran \& Mullins, 1979; Srinivasan $\&$ Mullins, 1980; Faure, 1990). In a morphological, histological and histochemical analysis of $V$. rupestris somatic embryos, it was noted that only $3 \%$ of the embryos could develop into plantlets. The rest displayed several abnormalities such as acquisition of giant and teratologic organs, highly regenerative capacity of superficial cells, starch and tannin accumulation, etc. in comparison with zygotic embryos (Faure, 1990). It was suggested that the high humidity conditions typical of in vitro cultures might inhibit germination, accounting for some of the problems experienced.

A few elegant histological studies confirmed the similarity of grapevine somatic and zygotic embryo development from the globular to the torpedo stage. It was also shown that somatic embryos displayed two apical meristems from the end of the globular stage onwards to the torpedo stage. The low conversion rate into plantlets is therefore not due to the absence of a shoot meristem in the developing embryo (Faure et al., 1996a). However, it was clear from this analysis that embryo bilateral symmetry was not established, as evidenced by the irregular crown-like cotyledon development around the shoot meristem. As referenced by Faure et al. (1996a), Liu et al. (1993) proposed the possibility that this phenomenon could be due to disruption of the normally polarised auxin transport in the young embryo. Moreover, it seemed that the shoot meristem, present until the torpedo stage, differentiated and became non-meristematic as successive stages of embryogenesis occur, probably leading to the generalised observation that somatic embryos lack shoot meristems (Mullins \& Srinivasan, 1976; Krul \& Worley, 1977). The abnormal development of the somatic embryos giving rise to the giant structures is thought to be due to precocious germination, a process that has been attributed to continuous and simultaneous expression of embryogenic and post-embryogenic development programmes (Faure \& Aarrouf, 1994; Faure et al., 1996a).

Several approaches have been adopted to circumvent and/or manipulate these problems typical of somatic embryogenesis to successfully regenerate normal grapevine plantlets. It seems that daily subculturing to fresh medium and low cell densities are optimal to manipulate PEMs through the embryo development phases to yield mature plants (Coutos-Thévenot et al., 1992a, b; 1993; Maes et al., 1997). It was shown that extracellular proteins in the culture media modulate embryo development and that some of the proteins have an inhibitory role. Some of the proteins identified in the culture medium of arrested embryo cultures included various glycoproteins, a cationic peroxidase and a lipid transfer protein (Coutos-Thévenot et al., 1992b). The suggested daily subculturing and the low inoculation rates relieved the inhibitory effects of the identified extracellular proteins, leading to a marked improvement in the regeneration capacity of normal plantlets (Coutos-Thévenot et al., 1992a). The addition of proteases and protease inhibitors to cultures confirmed the notion that extracellular proteins modulate somatic embryogenesis, and provided evidence for a proposed extracellular proteolitic mechanism during somatic embryo development (Maes et al., 1997).

Several other adaptations have been employed to improve normal plantlet development. These include chilling, section of cotyledons, addition of cytokinins and dehydration, which all improved the low conversion rates. Perl et al. (1995) succeeded in high percentages of germination with cultivar Sultana, but observed equally high $(80-90 \%)$ rates of abnormal plantlets. These plantlets could be induced to form normal shoots when transferred to medium containing $\alpha$-naphthaleneacetic acid (NAA) (Perl et al., 1995).

It was also observed that transformed as well as untransformed plantlets regenerated from somatic embryos had atypical Sultana features (Franks et al., 1998; Robinson et al., 1999). These included lobed leaves with red veins and anthocyanin accumulation in stems and petioles (Franks et al., 1998), and are considered a departure from trueness to type. Evidently, these symptoms correspond with phenotypes of grapevines grown from seed and most probably constitute a juvenile phenotype which is presumed to be replaced by the adult phenotype once the plant bears fruit (Robinson et al., 1999).

\section{Transformation of grapevine}

The plant biotechnology era swung into full motion after the possiblity to use the natural plant pathogen, Agrobacterium tumefaciens, as a plant transformation tool was first reported (De Block et al., 1984). Grapevine had generally been regarded as recalcitrant to genetic transformation due to the initial difficulties experienced in the introduction of foreign genes and the selection and regeneration of transformed cells in this species (Perl \& Eshdat, 1998). Five years passed after the initial report on tobacco transformation before Baribault et al. (1989) showed that cultured grapevine cells could be transformed with A. tumefaciens, the disarmed transformation agent of herbaceous annual plants. Several excellent and comprehensive reviews have been published (Perl \& Eshdat, 1998), or are currently in press (Martinelli \& Mandolino, 2000), on the advances made in grapevine transformations, and therefore the sections below only briefly summarise the important concepts regarding the methods of transformation as well as the problems of tissue-necrosis and selection of transformed grapevine cells.

Agrobacterium-mediated genetic transformation of grapevine: A. tumefaciens, the workhorse of plant biotechnology, belongs to the Rhizobiaceae family, which also includes the species A. rhi- 
zogenes, A. vitis (previously A. tumefaciens biovar 3), $A$. radiobacter and $A$. rubi. Characteristic of these species is their ability to transfer a discrete part of their plasmid DNA (T-DNA) into plant cells to cause crown gall or hairy root disease (in the case of A. rhizogenes) of several dicotyledonous plants (Ophel \& Kerr, 1990; Hooykaas \& Schilperoort, 1992; Yanagi \& Yamasato, 1993). Most of the successful transformation protocols utilising Agrobacterium as a transformation agent use disarmed A. tumefaciens (biovar 1) strains, and the wide host range of this species establish it as an excellent transformation agent.

During the Agrobacterium-infection process, DNA transfer is preceded by an intimate association between the bacterium and the plant cell based on chemotaxis and chemical recognition (Spencer et al., 1990). This, in overly simplified terms, forms the basis of the host range of Agrobacterium and relies on the induction of the virulence (vir) genes by plant phenolic compounds. It has been found that certain strains of $A$. tumefaciens (biovar 3 strains) exclusively form crown galls on cultivars of $V$. vinifera, and these strains have been elevated to species level to comprise A. vitis (Tomashow et al., 1980). These strains cause crown gall and root decay of grapevine and the most predominant group (the octopine-cucumopine strains) can be divided into wide host range (WHR) and limited host range (LHR) strains, based on their oncogenic ability towards host plants other than grapevine (Paulus et al., 1991). The WHR strains are tumourogenic on grapevine as well as on tobacco and tomato hosts, whereas LHR strains form tumours only on grapevine (Paulus et al., 1991). It has also been observed that some strains of A.tumefaciens cause a hypersensitive response on leaves, stems and petioles, but fail to form tumours on grapevine (Yanofsky et al., 1985; $\mathrm{Pu}$ and Goodman, 1992, 1993). The fact that Agrobacterium is in fact a pathogen of grapevine has complicated its use as a transformation agent for this crop, since the plant responds defensively to the presence of the bacterium.

The first successful transformations of grapevine (Baribault et al., 1989, 1990; Mullins et al., 1990) have proven that disarmed $A$. tumefaciens strains, harbouring either a co-integration or a binary plasmid, can stably introduce a foreign gene into the grapevine genome. These and other attempts to establish direct organogenesis as the basis of transformation protocols failed to a large extent in grapevine. Several singular reports (which could never be repeated) appeared on the successful regeneration of transformants from infected apical meristems (Hung \& Mullins, 1989) and petiole explants (Mullins et al., 1990). Baribault et al. (1990) observed that transgenic shoots regenerated from infected fragmented shoot apices were chimeric in nature. This problem, as well as the inhibitory effect of the selective agents on plant regeneration, formed the basis upon which direct shoot organogenesis was essentially dismissed as a reliable and reproducible method for Agrobacterium-mediated transformation of grapevine cultivars (Perl \& Eshdat, 1998). It was shown by anatomical and histochemical analyses that although regenerating leaf explants displayed high rates of adventitious shoot formation (70-90\% for the cultivars tested), no transgenic shoots were observed (Colby \& Meredith, 1990; Colby et al., 1991). As explained by Perl \& Eshdat (1998), this could be attributed to the fact that Agrobacterium commonly transforms cells in the cut surface of the petiole, an unregenerable region. From these and other stud- ies, it became evident that the recalcitrance of grapevine towards genetic transformation can be attributed mostly to the need for relatively high concentrations of the selection agents and the concomitant inhibitory effect of these agents on regeneration in direct organogenesis schemes.

Agrobacterium-based transformations of grapevine utilising somatic embryo cultures were much more successful, and several high efficiency and reproducible transformation protocols are currently in use. The proembryogenic cell-lines described in the previous sections are excellent target material for co-cultivation, and when combined with liquid cultures, are optimally suited for production of numerous transgenics of single cell origin. Both Vitis rootstocks and $V$. vinifera cultivars have been successfully transformed utilising co-cultivated somatic embryos (Le-Gall et al., 1994; Martinelli \& Mandolino, 1994, Krastanova et al., 1995; Martinelli, 1995; Mauro et al., 1995b; Perl et al., 1996a; Franks et al., 1998). Apart from the critical role the quality of the cell culture plays in grapevine transformation, the following generalisations pertain to most of the protocols used: (i) wounding of the embryogenic cells is not necessary for optimal DNA transfer, but the addition of acetosyringone improves the virulence of the Agrobacterium-transformation agent; (ii) the length of cocultivation, together with the cell density of the Agrobacterium culture may influence the necrotic response of the tissue and the transformation efficiencies; and (iii) the effects of the cells towards the transformation and the selection agent are significantly influenced by the genotype of the tissue (Le-Gall et al., 1994; Martinelli, 1995; Krastanova et al., 1995; Perl \& Eshdat, 1998).

The problems of necrosis and selection in Agrobacterium genetic transformation of Vitis: It is now well established that Agrobacterium infection and gene integration are not the limiting factors in grapevine transformations, but problems linked to tissue necrosis, selection and regeneration still limit the number of successfully transformed grapevine cultivars.

Necrosis: Two types of necrogenesis have been observed in the association between grapevine tissues and Agrobacterium strains. The first type has been observed on whole plant grapevine explants such as leaves, petioles and stems when inoculated with strains of Agrobacterium spp. A spreading hypersensitive-type reaction develops after approximately seven days at the point of infection ( $\mathrm{Pu} \&$ Goodman, 1992). This characteristic reaction was observed for most Agrobacterium spp. and varied in severity in a cultivar-specific manner ( $\mathrm{Pu} \&$ Goodman, 1992). It was later shown that this type of tissue decline relies on the presence of the T-DNA within the infecting strain, since in the absence of T-DNA, the strains lost both the ability to induce tumours and necrosis (Deng et al., 1995).

The second type of necrogenesis is observed when grapevine somatic embryogenic cell-lines are exposed to A. tumefaciens transformation strains, and is strictly cultivar specific in the severity of the reaction. This type of tissue necrosis is a limiting factor in achieving success with transformation and regeneration of several grapevine cultivars. The necrosis typically occurs $48 \mathrm{~h}$ onwards after cocultivation and can in some cases be so severe that the target material never becomes proliferative again. Perl et al. (1996a) showed that the necrotic response could be attributed to an oxidative burst and that peroxidases and other defencerelated proteins are involved in the response. Similar results were 
obtained when the defence response of grapevine cells towards a fungal elicitor was analysed (Calderon et al., 1993, 1994). Interestingly, this type of necrosis is not dependent on the presence of the T-DNA in the infecting strain and is caused by A. tumefaciens (biovar 1) strains, but not A. vitis strains (Fig. 5) (Perl et al., 1996a; Joubert et al., 2000). Based on the fact that embryogenic cell-lines in a more advanced stage of embryo development exhibited more severe tissue necrosis than cell-lines consisting of mainly PEMs, it has been suggested that the necrosis phenomenon is not only cultivar specific, but also developmentally regulated (Perl \& Eshdat, 1998). It is now known that the response is most probably initiated by an Agrobacterium genome-encoded protein (Perl \& Eshdat, 1998) that has similarities to a harpin protein.

Fortunately, several advances have been made in understanding and manipulating the necrotic effect observed on cell-lines after cocultivation with $A$. tumefaciens strains. A combination of antioxidants have been found optimal in limiting necrosis of embryogenic material and improving plant viability (Perl et al., 1996a, b). The addition of polyvinylpolypyrrolidone and dithiothreitol as antioxidants to the cocultivation and tissue proliferation media dramatically decreased, or abolished, necrosis and tissue death (Perl et al., 1996a). Moreover, it was confirmed that these treatments did not adversely affect either the infection rate or Agrobacterium virulence (Perl et al., 1996a; Torregrosa et al., 2000). By using PEM cultures instead of more differentiated embryo cultures, it is also possible to limit necrosis (Perl \& Eshdat, 1998).

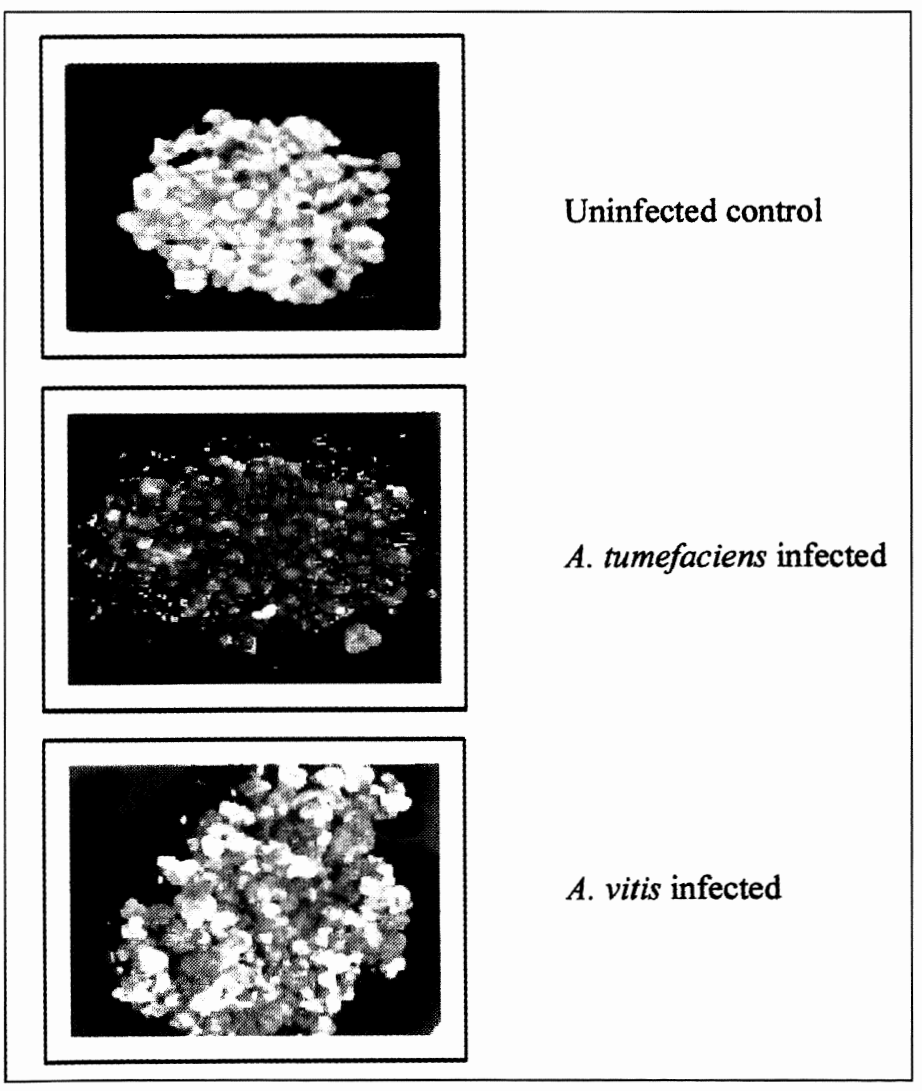

FIGURE 5

The different effects regarding necrosis of Agrobacterium tumefaciens and A. vitis on grapevine somatic embryos (Joubert et al., 2000).
Another possible approach to extend transformation of grapevine to more cultivars without the problems of necrosis is to use disarmed $A$. vitis strains as transformation agents of grapevine. These strains do not induce tissue necrosis of grapevine embryogenic material and are naturally very efficient pathogens of grapevine. Disarmed A. vitis strains might therefore prove to be more effective in their ability to attach to and colonise a vast range of grapevine cultivars, as well as not inducing necrosis of the embryogenic target material. To this end Joubert et al. (2000) has isolated and characterised an $A$. vitis strain as a possible transformation agent. The disarmed strain is currently being evaluated for its inability to form tumours and necrosis as well as improved transformation efficiency relative to A. tumefaciens transformation agents (Joubert et al., 2000).

Selection: Several conflicting reports appeared regarding the sensitivity of regenerating grapevine tissues toward selection agents such as kanamycin and hygromycin. In some instances, high resistance toward regenerating explants were noted (Hung \& Mullins, 1989), whereas other workers found extreme sensitivity of the same explant type toward the selective agent (Baribault et al., 1990). These and other conflicting reports have confirmed that the resistance of regenerating material to selective agents varies with explant and cell-type, cultivar, culturing method and selective agent used (Colby \& Meredith, 1990; Mullins et al., 1990; Colby et al., 1991). Complicating the selection of transformed grapevine tissue even further is the fact that pre- and posttransformed tissue differ in their base-line sensitivities toward the introduced selective agent.

Optimal selection and regeneration seems to occur with minimal elapsed time between the transformation event and the onset of regeneration under selection; this has been achieved in a liquid culture system consisting of PEMs after cocultivation selection commenced immediately with frequent changing of the medium (Perl \& Eshdat, 1998). As soon as embryo formation progressed to the cotyledonary stage, the cultures were plated on selective germination medium. Very good results were obtained with paromomycin or kanamycin as selection agents, but the former is preferred since it is capable of inducing cell-death in non-transformed tissues in approximately three days (Mauro et al., 1995b; Perl \& Eshdat, 1998), thereby providing a very efficient selective system. Recent results showed that this method is also very effective in co-transformation and co-selection protocols. By using Agrobacterium-mediated genetic co-transformation, employing two vectors carrying two different selectable marker genes, respectively and three disease resistance genes, transgenic plantlets could be regenerated and confirmed to contain the introduced genes (Colova-Tsolova et al., 2000; Perl et al., 2000). It is clear from the significant advances made in Agrobacteriummediated transformation of grapevine varieties that gene technology is becoming a feasible reality in viticulture.

Biolistic bombardment: The biolistic bombardment process relies on the acceleration of inert nucleic-acid coated heavy metal particles such as gold or tungsten to specific velocities able to penetrate the target biological material (Klein et al., 1987). The fact that this method relies on a physical process rather than a biological interaction simplifies its extension to theoretically any regenerable tissue or cell. It has therefore found wide application in the transformation of bacteria, filamentous fungi, yeast, algae, 
animal cells and organs and higher plant cells, tissues and organelles (Sanford et al., 1993; Birch, 1997). In the Plant Kingdom, the primary application of this system has been the transformation of species resistant to the conventional Agrobacterium methods, and is widely used in the transformation of monocotyledonous plants (Birch, 1997). It has also been extended to grapevine in an optimisation study where diverse parameters such as optimal particle size, microprojectile travelling distance, helium pressure and DNA concentrations were studied (Hébert et al., 1993). Due to the successes obtained in this study and the availability of refined protocols for the regeneration of bombarded embryogenic material (Hébert-Soulé et al., 1995), it was possible to regenerate transgenic grapevine plants expressing a bacterial $\beta$-glucuronidase gene (GUS) (Kikkert et al., 1996) as well as a chitinase gene of Trichoderma (Kikkert \& Reisch, 1996).

The technical equipment and expertise required, the degree of optimisation involved in the establishment of a suitable bombardment protocol for a specific cultivar, and the difficulties of selection and regeneration of grapevine tissues has limited the wide application of this technology in grapevine transformations. Biolistic bombardment has also been used in combination with Agrobacterium-mediated transformation to generate transgenic table grape plantlets (Scorza et al., 1996). The bombardment was used as a wounding mechanism and was followed by cocultivation with a disarmed A. tumefaciens strain. The main objective of the pre-cocultivation bombardment was to increase transformation efficiencies, but due to a limited numbers of regenerants obtained, it was difficult to reach a conclusion on the importance of the wounding-step. Biolistic bombardment remains a versatile technology that is also very useful for monitoring transient expression of transgenes, rendering it very attractive for genetic studies such as promoter analysis or in planta testing of vector constructs before the more lengthy process of stable transformation is attempted (Birch, 1997).

\section{Targeted traits in the genetic improvement of grapevine}

The two main areas of study in grapevine biotechnology are undoubtedly disease management and berry ripening. Most groups aiming at enhancing these aspects also study the various processes of pathogenesis, cell wall structure and morphogenesis, plant-pathogen interactions, signal transduction of infection stimuli and sugar-acid metabolism. In-depth knowledge on these and other related subjects is key to the successes obtained in the manipulation of these processes. The biotechnological applications therefore rely heavily on the availability of fundamental knowledge as well as technologies to identify, isolate and characterise target genes and useful promoter sequences (Robinson et al., 1999).

Enhancing disease resistance: Plants have evolved a number of mechanisms to curb attacks by pathogenic fungi, bacteria, viruses and insects. These include structural barriers, such as waxy cuticles or strategically positioned hydrolysing enzymes and/or antimicrobial compounds that function to prevent colonisation of the tissue (Agrios, 1997). Plants also use induced or active cellular defence mechanisms to prevent further colonisation of the tissue when the structural barriers of the host have been breached. Active defence responses are induced by all classes of plant pathogens and typically follow a cascade effect. The primary response is usually elicited in the cells directly in contact with the pathogen, subsequently leading to a secondary response in surrounding cells due to diffusible elicitor molecules originating from the primary responses. The final stage of the active defence response is associated with systemic acquired resistance hormonally induced throughout the plant (Agrios, 1997).

Fungal resistance: Most of the strategies employed to manipulate disease resistance in plants involve up-regulation of one or more of the aforementioned defence strategies. Proteins present at low levels in healthy plants that are more abundantly produced during pathogen attack have been termed pathogenesis-related (PR) proteins (Jach et al., 1995). This diverse group of proteins includes hydrolytic enzymes such as chitinases and $\beta$-1,3-glucanases. Several classes of plant glucanases and chitinases have been identified and their suspected antifungal activities have been confirmed by in vitro tests. These proteins are able to break down the structural polysaccharides in fungal cell walls and their encoding genes have therefore been targeted as antifungal genes in various genetic manipulation procedures (Oppenheim \& Chet, 1992; Zhu et al., 1994; Jongedijk et al., 1995; Busam et al., 1997; Kikkert et al., 2000).

Similarly, in grapevine, a direct correlation between the activity of $\beta$-1,3-glucanases and chitinases and the resistance rating of different grape genotypes to powdery mildew (Oidium tuckerii) has been found (Giannakis et al., 1998). Glucanase and chitinase enzymes purified from leaves of a resistant cultivar showed inhibition to powdery mildew in a bioassay, confirming their antifungal properties (Giannakis et al., 1998; Robinson et al., 1999). Since a number of chitinase and glucanase-encoding genes from grapevine have been isolated (Derckel et al., 1996), their regulation and mode of action are currently being studied (Robinson $e t$ al., 1997, 1999).

Genes encoding chitinase and/or $\beta$-1,3-glucanase proteins from various sources have been overexpressed in several plant spp., resulting in increased resistance to fungal pathogens in the transgenic plants (Oppenheim \& Chet, 1992; Zhu et al., 1994; Jongedijk et al., 1995; Busam et al., 1997). This approach has also been used in grapevine, and several transgenic lines containing either plant or fungal-derived PR proteins are currently under evaluation and/or in field trials (Kikkert et al., 1996; Perl \& Eshdat, 1998; Bornhoff et al., 2000). In vitro tests with various glucanase and chitinase proteins from the yeast Saccharomyces cerevisiae have also shown very good inhibition of spore germination and hyphal growth of Botrytis cinerea (Fig. 6). These potential yeast derived PR-proteins are currently being evaluated in planta as antifungal agents against Botrytis and other fungal pathogens (Vivier et al., 2000).

Other antifungal strategies in grapevine include the use of the stilbene synthase and phenyl ammonia-lyase genes from grapevine (Melchior \& Kindl, 1991) and ribosomel inactivating proteins (RIP) (Perl \& Eshdat, 1998; Bornhoff et al., 2000). Another possible strategy under investigation involves the use of genes encoding antifungal peptides that are active against fungal pathogens. Several plant spp. use antimicrobial peptides against a range of pathogens, primarily by disruption of membrane function. In a study to evaluate the effectiveness of peptides isolated from plant spp. such as Allium (Cammue et al., 1995), Dahlia (Osborn et al., 1995), Heuchera (Osborn et al., 1995) and 


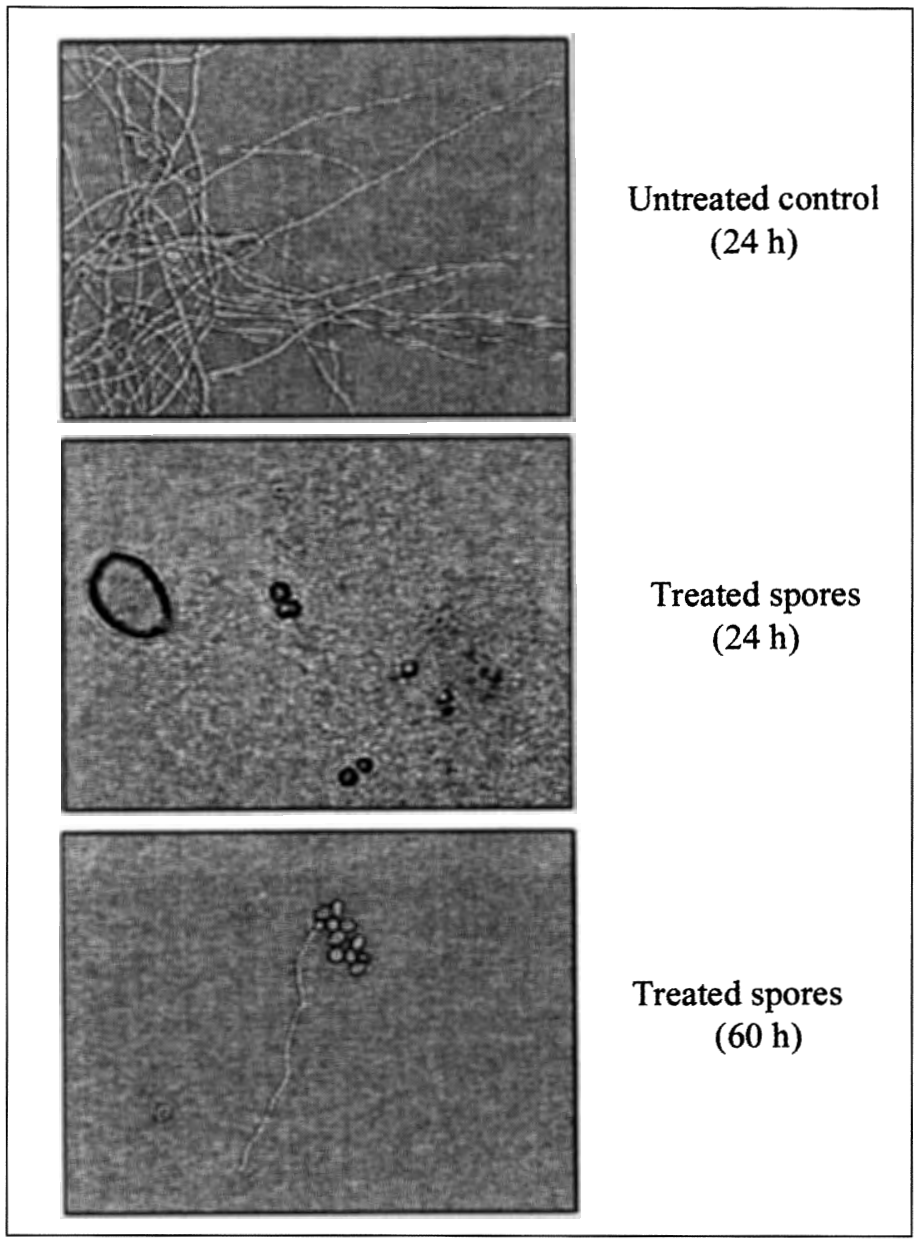

FIGURE 6

The effect of yeast $\beta$-1,3-glucanase and chitinase proteins (in combination), secreted by a recombinant Saccharomyces cerevisiae, on Botrytis cinerea spore germination and hyphal growth in an in vitro inhibition assay. Spore disruption and leakage was observed after $24 \mathrm{~h}$ of incubation, whereas much reduced hyphal growth and overall biomass production was observed after $60 \mathrm{~h}$, when compared to the untreated control (Vivier et al., 2000).

Raphanus (Terras et al., 1991), significant hyperbranching and inhibition of Botrytis hyphal growth was observed in an in vitro bioassay (Fig. 7) (Vivier et al., 2000). The possible effectiveness of these proteins in transgenic grapevine plants is currently being evaluated.

One class of plant proteins that is well established in disease resistance are the polygalacturonase-inhibiting proteins (PGIPs) (Brown \& Adikaram, 1982; Abu-Goukh et al., 1983; Cervone et al., 1987). These membrane-bound proteins interact specifically with polygalacturonases released by invading fungal pathogens, thereby inhibiting the infection process of the fungus (Cervone $e t$ al., 1986; Leckie et al., 1999). PGIP-encoding genes have been isolated from numerous plant spp. and typically constitute a gene family (Cervone et al., 1987; Favaron et al., 1994; Stotz et al., 1994; Ramanathan et al., 1997). These genes form part of the broader class of resistance genes in plants, and their expression levels are usually induced upon pathogen attack and wounding (Yao et al., 1999). Several overexpressed PGIPs have been used

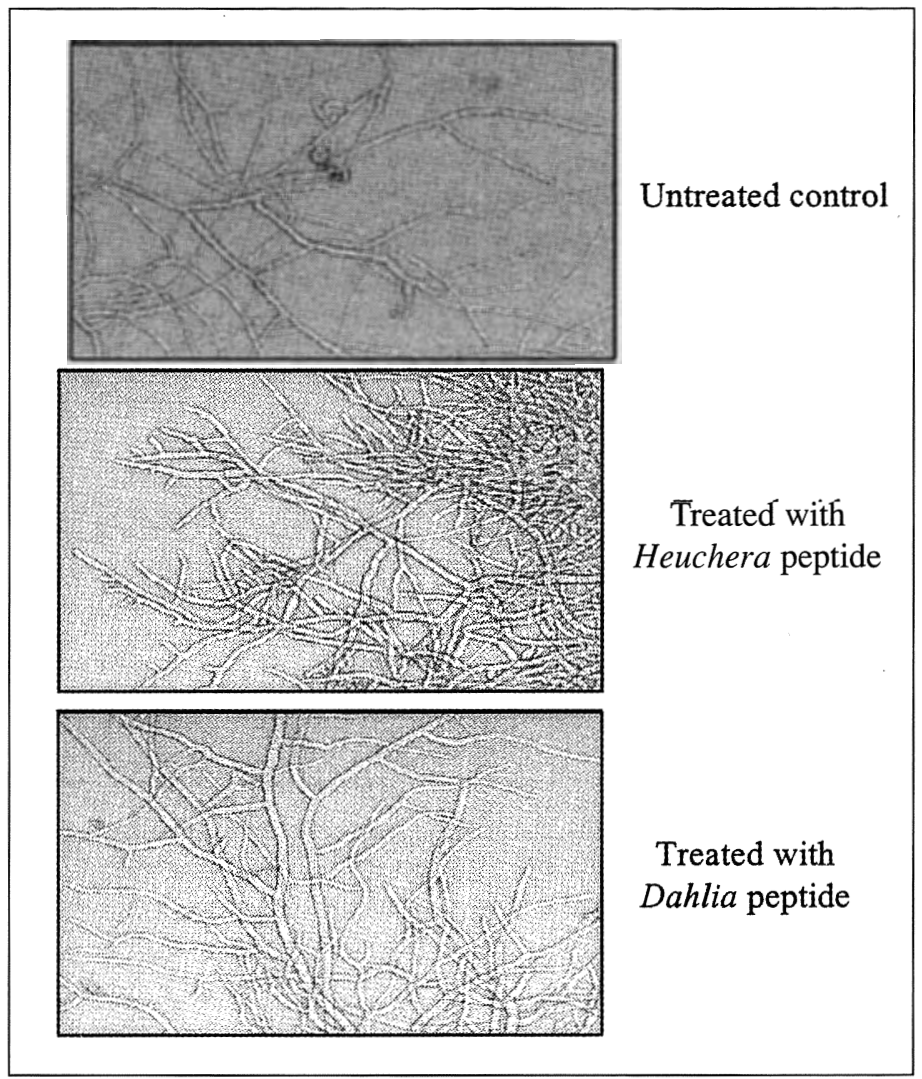

\section{FIGURE 7}

The effect of two antifungal peptides $(6 \mu \mathrm{g} / \mathrm{ml})$ from Heuchera and Dahlia, respectively, on Botrytis cinerea hyphal growth in an in vitro inhibition assay. Both caused severe hyphal hyperbranching and overall reduction in biomass when compared to the untreated control (Vivier et al., 2000).

in plant hosts to enhance disease resistance with varying success, and it might prove to be a successful strategy in grapevine as well. Apart from the manipulation potential of the proteins, the encoding genes and their promoters also provide significant insight into plant-pathogen interactions, protein-protein interactions and the transducing of infection signals and resistance responses.

Virus resistance: The manipulation of virus resistance in grapevine by gene technology has been actively investigated ever since transformation protocols were successfully applied to Vitis. The importance of virus resistance is evident when considering that there are approximately 47 recognised virus and virus-like diseases recorded from grapevine (Martelli, 1993; 1999). The most harmful viruses on grapevine include the nepoviruses (ten different species), closteroviruses (eight different species), vitiviruses and grapevine fleck viruses (Martelli, 1999). Quantitative studies have confirmed the deleterious effects of viruses on grapevine growth and health, including low quality and quantity of yield, reduced graft-take and rooting ability of propagation material, and reduced production life of the grapevine (Walter \& Martelli, 1997).

Once inside a plant, some viruses can be inactivated by heat (Goussard \& Wiid, 1992). Typically, this involves the dipping of 
dormant, propagative organs in hot water $\left(35-50{ }^{\circ} \mathrm{C}\right)$ for a specified time (Martelli, 1993), or the incubation of actively growing plants in glass houses or growing chambers at elevated temperatures. These measures, as well as tissue culture techniques such as apical- or root meristem cultures and somatic embryogenesis can ensure that starting material are essentially virus-free (Minck et al., 1998). Unfortunately, due to the fact that viruses can spread from plant to plant in a number of ways, including vegetative propagation and mechanical transmission through plant sap, seed, pollen, specific insects, mites, nematodes and fungi, the possibility of re-infecting the "clean" material is very high (Agrios, 1997).

One of the most successful ways of introducing more permanent resistance in crop plants is through pathogen-derived resistance (PDR) (Sanford \& Johnston, 1985; Prins \& Goldbach, 1996). PDR can be explained as the expression of a pathogenderived gene and its encoding product at either an inappropriate time, or in an inappropriate form or amount during the infection cycle, thus preventing the pathogen from maintaining its infection (Agrios, 1997). PDR was first shown to be effective in 1986 (Powell-Abel, 1986) when it was reported that transgenic tobacco plants expressing the tobacco mosaic virus (TMV) coat protein (CP) were resistant to subsequent infection with TMV.

Although coat protein- $\underline{m}$ ediated $\underline{r}$ esistance (CP-MR) has since been shown to be effective against more than 20 different viruses, the resistance obtained is specific and does not necessarily provide protection to related and unrelated viruses. This strategy has also been used in grapevine manipulations of rootstock and scion varieties to provide potential resistance against some grapevine viruses. Normal and mutated coat proteins of grapevine fleck virus, nepoviruses, vitiviruses and leafroll closteroviruses have been introduced into scion and rootstock varieties (Krastanova et al., 1995; Mauro et al., 1995b; Minafra et al., 1997; Xu et al., 1997; Gölles et al., 2000).

At least seven closteroviruses, however, are associated with some of the grapevine virus diseases, such as grapevine leafroll disease. Grapevine closteroviruses have a genome consisting of single stranded sense RNA of approximately 18000 nucleotides in size. Due to this fact, it is important to develop a control strategy that offers broad-spectrum resistance to each of these viruses. Movement protein-mediated resistance (MP-MR) has been reported to offer resistance to a broad spectrum of related and unrelated viruses. However, the level of resistance obtained with MP-MR is not as high as can be achieved with CP-MR. Research has shown that the best levels of resistance are obtained when the movement protein is disrupted to produce a dysfunctional protein (Beck et al., 1994; Tacke et. al., 1996; Seppanen et al., 1997). The dysfunctional movement protein interferes with the functioning of the wild-type movement protein in a dominant-negative manner and thus prevents key processes required for mobilisation of the virus genome from cell to cell (Soellick et al., 2000). This strategy is also currently employed as a possible resistance strategy against grapevine viruses such as vitiviruses (Martinelli et al., 2000a, b) and grapevine closteroviruses.

Virus manipulation with gene technology is also benefiting from molecular detection methods to accurately and sensitively assess the virus status of plants, even if infection is latent or symptom-free. Moreover, advances in micrografting techniques
(Ollat et al., 2000) are ensuring that transgenics plants, containing one or more of the resistance mechanisms, can be evaluated for true resistance much faster.

The study of grape berry ripening: Berry growth and ripening follow a specific growth-pattern after flower set, typically displaying a double-sigmoidal growth curve with three distinctive stages. The first stage involves cell divisions with subsequent cell expansion, whereas the third phase almost exclusively involves cell enlargement (Coombe, 1992). The second phase constitutes a lag phase with no real size increase, but exhibits intense metabolic activity and re-programming. In viticultural terms, the end of this phase is commonly termed véraison, corresponding to the inception of the colour change and signaling the onset of ripening in the grape berry. Through these successive stages the berry develops into the coloured, soft, juicy, sweet and flavoursome fruit that is suitable for winemaking and other purposes (Coombe, 1992).

The improvement of berry quality using gene technology focuses primarily on aspects of colour development, sugar-acid metabolism and seedlessness in table grape varieties. The biotechnological application of these aspects is yet to be realised, since most of the work being done in this regard is still aimed at elucidating the underlying mechanisms. All of these processes are intricately controlled and the isolation of genes and promoters that are berry-specific, developmentally regulated and expressed in certain stages of berry growth and ripening, have significantly advanced knowledge of the various underlying molecular mechanisms of grape berry ripening (Robinson, et al., 1999).

Regulation of sugar- and colour accumulation: Major changes are observed regarding sugar-acid balances and anthocyanin production post-véraison (Coombe, 1992; Davies \& Robinson, 1996). The major solutes accumulating in grape berry vacuoles are glucose and fructose, originating from sucrose. The sucrose is translocated in the phloem from source organs (leaves and storage organs) to the ripening grape berries (sink organs) (Coombe, 1992). In grapes, the pathways of sugar loading/unloading are still poorly understood and it is still not clear whether phloem loading/unloading proceeds symplastically or apoplastically (Fillion et al., 1999). It seems that numerous plasmodesmata connecting the flesh cells of storage parenchyma in the berry, and significant plasma membrane surface area on the phloem/storage parenchyma interface, provide scope for either of the loading mechanisms (Fillion et al., 1999).

The flux of sugar transport into a sink organ such as a berry is dependent on either sugar utilisation and/or compartmentalisation. It is still unclear exactly where sucrose hydrolysis occurs during the post-véraison hexose accumulation phase. It has been shown that the bulk of the invertase activities in berries are soluble. Two vacuolar invertase-encoding genes have been isolated from grape berries (Davies \& Robinson, 1996) and shown to have increased expression levels well in advance of the rapid hexose accumulation phase. This result seems to suggest that the synthesis of invertase is not linked to the rapid accumulation of hexoses in the berry vacuole, and that other factors probably play a regulatory role (Davies \& Robinson, 1996; Davies et al., 1997). Sucrose synthase activity is also low during the maturation of the berries (Hawker, 1969), again hinting at a control mechanism of compartmentalisation rather than sugar utilisation or metabolism 
in the ripening grape berry (Fillion et al., 1999).

Recently, sucrose and hexose transporter-encoding genes have been isolated from grapevine (Fillion et al., 1999; Ageorges et al., 2000; Atanassova et al., 2000; Davies \& Robinson, 2000b) and are currently under investigation. A study of one of the hexose transporters from grapevine showed that the cDNA sequence shared strong homology (70-78\% identity) with other hexose transporters from herbaceous hosts (Fillion et al., 1999; Atanassova et al., 2000). Studies revealed two peaks of expression in berries, with the first peak at anthesis and the second major peak occurring approximately five weeks after véraison (Fillion et al., 1999). Another population of hexose transporters has been identified that exhibited high expression levels earlier during ripening (Atanassova et al., 2000). The fact that plasma membrane hexose transporters are expressed during the postvéraison stage seems to suggest that at least some of the sucrose imported into the ripening berry is already hydrolysed before accumulation occurs in the flesh cells (Fillion et al., 1999).

The putative promoter of the isolated hexose transporter also revealed several potential cis elements such as ethylene- or abcisic acid (ABA)-responsive elements. Promoter deletion constructs, using reporter genes, are evaluated in tobacco and grapevine transformants to analyse the role of these elements. Preliminary results seem to suggest that the hexose transporter from grapevine (encoded by $V v h t l$ ) is at least under partial control of glucose (Atanassova et al., 2000). These approaches, as well as analyses of grapevine mutants overexpressing a yeast invertase gene targeted either to the apoplast, cytoplasm or vacuole (Esterhuizen et al., 2000), should help to clarify some questions regarding sugar transport and the control of sugar accumulation in ripening grape berries.

Coinciding with the accumulation of hexoses in the ripening berry is the increase in the formation of anthocyanins leading to the characteristic skin colour of the berries. There is a range of anthocyanins present in grapes with similar basic structures, differing only in the amount of secondary chemical modifications. In grapes, anthocyanins are produced by the flavonoid pathway consisting of several successive enzyme reactions which convert colourless precursor molecules into coloured anthocyanin compounds (Boss et al., 1996a). Several of the genes involved in flavonoid biosynthesis in grapevine have been cloned (Sparvoli et al., 1994) and were used to study the control of anthocyanin biosynthesis during berry ripening (Boss et al., 1996a, b). Although some of the genes in the early part of the pathway were expressed in the earlier phases of berry development (without the detection of anthocyanins), all of the genes were induced at veraison, coinciding with anthocyanin accumulation (Boss et al., 1996a). From these studies and expression analyses comparing white, red and black grape varieties, it was clear that one of the last proteins in the pathway represents a controlling step in the production of anthocyanins in grapevine (Boss et al., 1996a, b, c). This control step was attributed to UDP glucose flavonoid-3-glucosyl transferase (UFGT) which was not expressed in unpigmented tissues of Shiraz berries, nor in the skins of white cultivars (Boss et al., 1996b).

What triggers ripening?: Grapevine is considered a nonclimacteric fruit and the exact nature of the signal initiating the ripening process in grapes is not yet known. In many fruits the ripening signal is hormonally induced, frequently by ethylene. From previous studies it has been shown that ethylene levels are low in grapes and do not increase during the ripening phases (Coombe \& Hale, 1973; Alleweldt \& Koch, 1977). Other hormones implicated in fruit ripening of plant spp. include auxin and ABA. In grapes, auxin reaches a maximal level just after anthesis, subsequently decreasing to very low levels post-véraison (Cawthon \& Morris, 1982). Moreover, exogenous application of a synthetic auxin, benzothiazole-2-oxyacetic acid (BTOA), delays the ripening of grape berries (Davies et al., 1997). In contrast, it seems that ABA levels increase in ripening berries and that ripening is delayed when ABA-increase is blocked (Hale \& Coombe, 1974). The synthetic auxin BTOA, was used to evaluate the effect on developmentally regulated genes by monitoring the expression of a putative vacuolar invertase, a chalcone synthase, UFGT, a chitinase and a ripening-related gene (Davies et al., 1997). From these results it was evident that the normal expression of these genes was altered by the BTOA. The invertase expression that usually decreases with the onset of ripening, extended beyond veraison, whereas expression of the other genes, which are usually induced at the onset of ripening, were delayed. It was also shown that the normal accumulation of ABA levels during ripening was delayed due to the BTOA treatments (Davies et al., 1997). These results support the case for a hormonal signal controlling the ripening process and it hints at the possible linkage of the control of auxin and ABA levels.

Ripening and stress: It seems that the ripening process in grape berries is a stress-associated process (Davies \& Robinson, 2000a). Ripening involves the influx of high concentrations of sugars as well as the concomitant rapid cell expansion and ripening-induced softening of the fruit. From a differential screening analysis, ripening-related cDNAs not present in unripe fruit were isolated and two groups of proteins could be identified (Davies \& Robinson, 2000a). The first group consisted of several examples of proteins putatively involved with cell wall structure and includes members of the diverse P/HRGP family that are thought to be involved in the strengthening of polysaccharide networks in cell walls (Sommer-Knudsen et al., 1998). These proteins might function in stabilising the rapidly expanding and "softening" cell wall during ripening, or alternatively be involved in pathogen elimination, since their expression in other species has been upregulated by pathogen attack. In grapevine, there also seem to be a developmentally controlled defence response during fruit ripening as evidenced by coordinate accumulation of antifungal proteins and hexoses (Saltzman et al., 1998).

The other group of proteins identified by the differential screening comprise stress-related proteins (Davies \& Robinson, 2000a). As argued by the authors, the adjustment to rapid increases in vacuolar hexose levels during ripening might involve proteins usually employed in stress management. Since ABA levels usually increase during ripening, it might be involved in the regulation of these putative stress-response genes as has been shown in many other instances (Bray, 1997).

Although several issues regarding grape berry ripening still need elucidation, these studies and others that will undoubtedly follow are rapidly providing a knowledge base that will drive suitable gene technology strategies in future. 


\section{COMPLICATIONS SURROUNDING THE APPLICATION OF GENE TECHNOLOGY IN THE VITICULTURAL SECTOR}

Although some technical difficulties regarding grapevine transformation and regeneration are currently limiting factors in the application of gene technology to viticulture, they are probably temporary and not the biggest impediments to the successful implementation of the resulting products. Patents covering many of the gene promoters, marker genes, vectors and transformation methods commonly used in plant transformations leave scientists little freedom to operate, and also limit the subsequent usefulness of the generated transgenic plantlets from a commercial viewpoint. More importantly, the worldwide public outcry against genetically modified organisms has confirmed that this is an area where science must proceed with caution (Smeaton, 1999). Factors involved in the application of transgenic vines such as controversies regarding intellectual property rights and the naming of transgenic vines are important, but consumer concerns and resistance regarding the technology threaten the implementation and potential benefits on a much more fundamental level.

\section{The naming of transgenic cultivars}

The seemingly academic debate as to the description and naming of transgenic grapevines has far-reaching implications for the field of Grapevine Biotechnology. The outcome of the debate will determine not only the procedure for description of genetically modified grape varieties, but also to a large extent their acceptance by grape-growers and winemakers and/or their commercial value in the marketplace.

It has generally been accepted that the complex issue of naming transgenic grapevines relies on several factors such as the source of the gene(s) introduced, the true-to-typeness of the transgenics when compared to the original cultivar/clone and the unchanged organoleptic and sensory qualities of the wines produced from the transgenics. Researchers can only now begin to address these issues, since field trials of grapevine transgenics has only recently commenced in various countries.

Transgenic grapevines: new varieties or clones of existing varieties?: New grape varieties are produced by plant breeders who combine the genetic backgrounds of existing varieties to achieve certain qualitative traits in the progeny. Once evaluated and found to be useful, such a grapevine could be classified as a new variety, always receiving a new name. On the other hand, spontaneous genetic variants might also be obtained through clonal selection, leading to the naming of a specific clone of the original variety, typically specified by clone numbers. Most of these clones probably differ from each other by several genes. It is important to note that these clones might deviate in general appearance as well as organoleptic or sensory characteristics from the original variety, but are still appraised as that variety (Meredith, 1999).

As discussed in previous sections, the targeted traits in Grapevine Biotechnology are predominantly resistance toward pests and diseases, abiotic factors, and/or quality improvements of the berries. In most of these cases, a single gene is added to the genome of the variety being transformed (Robinson et al., 1999), probably affecting less than $0.001 \%$ of the total plant DNA. The resulting transgenic can exhibit changes in vine characteristics due to the expression of the introduced gene(s) or to changes induced by the disruption of gene(s) through the gene insertion event. The introduced genes could come from diverse sources such as bacteria, fungi, viruses, plants, Vitis spp. other than $V$. vinifera or overexpressed $V$. vinifera genes. Depending on the strategy used, the transgenics could therefore contain either heterologous proteins or increased copies of $V$. vinifera proteins (Eibach, 1999; Walter, 2000). It is clear, however, that the ideal transgenic grapevine will have enhancements in the targeted trait, while all other essential and desirable characteristics of the vine and the wine of the original variety are retained.

When considering whether or not a transgenic variety should have a new varietal name, or be considered a designated clone of the original variety, several scenarios arise, each with a different outcome. Central to all these scenarios is the conformity or divergence from a typical reference product; e.g. the original variety or characteristic wine, which are used as key decisive factors in the naming of the transgenic product (Eibach, 1999; Walter, 2000). When a transgenic grapevine has been manipulated to enhance disease resistance towards a specific pathogen and the resulting wines exhibit the characteristics of the original variety, it could be considered to be the same variety, perhaps distinguished by a specific clone number, or a special designator, e.g. Chardonnay "Super" (Meredith, 1999; Walter, 2000). The advantages of a recognised varietal name will therefore not be lost if a transgenic, disease-resistant version of the original variety is the result. If the transgenic grapevine diverges from the original variety and is separable in genotypic, phenotypic and product evaluations, it should receive a new varietal name.

When abiotic resistances to adverse environmental conditions are successfully manipulated in grapevines, it would be possible to establish vineyards of traditional varieties in areas previously not suitable for such cultivation, perhaps even without the use of rootstocks if engineered disease resistant strategies are successful. This could lead to unique characteristic vine and wine features not comparable to the original variety. In these instances where it is not only the introduced gene products(s) that influence the character of the vine and wine, but also a different environment, it might be more difficult to follow the simple rule of "conformance or divergence" in the naming of the transgenic grapevine (Walter, 2000). The same argument could, however, be applied to the naming of progeny of traditional breeding programmes, or clonal selection aimed at abiotic resistances.

The development of transgenic grapevines with altered fruit qualities such as improved colour and flavour compound composition will probably result in a significantly different wine, and might merit a new varietal name (Eibach 1999; Walter, 2000). On the other hand, there are existing examples where clones of traditional cultivars have been selected based on a specific characteristic without the concomitant assignment of a new varietal name, e.g. musky Chardonnay (Walter, 2000).

It is clear that universally accepted rules are necessary to specify the methods to be used in the description of clones and/or varieties, specifically with regard to the ampelographic (phenotypic) versus molecular marker (genotypic) analysis (Eibach, 1999). Moreover, consensus should be reached as to the limits of variation tolerable within clonal and/or varietal designations before a new clone or variety should be named (Meredith, 1999). All these issues are complicated further by the issue of intellectu- 
al property rights on transgenic cultivars.

Transgenic grapevines: who owns them?: In traditional breeding programmes it is possible to protect the rights of the originator if the new variety has been licensed. This necessitates confirmation that the proposed new variety is sufficiently distinct from other existing varieties, that it is a novel product and is homogeneous and stable. The distinctness usually refers to a clearly different appearance and/or unique agronomic characteristics such as flavour or disease resistance (Meredith, 1999). The traditional wine cultivars that originated through spontaneous crosses cannot be protected in this way and are considered public domain (Eibach, 1999). Though selected clones from these cultivars may be certified, their propagation is not protected (Eibach, 1999; Walter, 2000).

Property rights regarding transgenic grapevines remain unresolved, but several factors play roles. It is possible that patents not registered by the originator of the transgenic variety cover the introduced gene(s) as well as the transformation method used. These parties would therefore also have claims to the developed variety. With regard to property rights of the originator it would be beneficial to assign a new name to a transgenic cultivar if it is distinct, homogenous and stable, especially if the original variety was in the public domain (Eibach, 1999). If the original cultivar itself was protected, however, the transgenic grapevine could only qualify as a new protected variety if it does not detract from the rights of the patent holder of the original cultivar (Meredith, 1999).

In the event that the transgenic vine is similar to the original variety, it might merely be considered a clone, which is not protected in most instances, especially if the original cultivar is in the public domain. It is clear that these contradictory forces influence the naming of transgenic grapevines and could, together with other limiting factors such as consumer resistance, inhibit the widespread use of transgenic grapes in the wine industry. On the one hand, it is important to protect newly developed transgenic vines by allocating new varietal names to them if they have distinctive and stable characteristics. On the other hand, if the transgenic vines and derived wines are essentially indistinguishable from the original varieties, it would be beneficial to the marketability of the product if the original varietal name were maintained. Meredith (1999) suggested a possible compromise in which a transgenic version of a traditional variety is considered a new variety for the purpose of intellectual property rights, but for commercial purposes, it should be permitted to include the original name in the designation of the transgenic vine.

\section{Consumer resistance}

The concept of genetic manipulation has provoked much debate, and invariably, as with any new technology, has been met with resistance. This resistance is multifaceted and involves complex issues such as moral and ethical concerns about the technology, food safety and security, the impact of GMO's on the environment and biodiversity, and questions about the real benefits of the technology (Brown, 1999; Gaskell et al., 1999; Renouf, 1999; Robinson, 1999; Skene, 1999; Smeaton, 1999). These topics have been extensively reviewed by other authors (Kling, 1996; Barrett et al., 1997; Franck-Oberaspach \& Keller, 1997; Cavan et al., 1998; Altman, 1999; Chamberlain \& Stewart, 1999; Gaskell et al., 1999; Robinson, 1999; Serageldin, 1999; Bizily et al., 2000; Polkinghorne, 2000; Wackett, 2000) and will not be covered by this review. A few perspectives, however, on the potential transition from consumer resistance to consumer acceptance will be raised.

There seem to be a significant gap at the moment between scientific knowledge and public perception, and although industry is driven by the former, the success of the technology is dependent on the latter (Renouf, 1999). In the food and beverage sector especially, it is the consumer who will make the ultimate decision whether to embrace or reject the technology and its products. It is therefore of paramount importance to provide full information about the technology in an open and transparant manner and to address all fears (rational and irrational) and misconceptions (Brown, 1999).

The way in which the debate is handled also has an effect on public perception (Gaskell et al., 1999). In Germany consumers are extremely negative towards the technology and its products, and little progress is being made in resolving the issues. There are only a few participants in the debate, and they usually have entrenched positions, leading to head-to-head clashes in the media (Renouf, 1999). In the Netherlands the debate is handled more informally, with a consultative, inclusive approach. This led to a mutual understanding and/or respect of the various viewpoints on the debated issues. Consumers are regarded as equal partners in the debate and as in Denmark, are generally critical of the technology, but not vehemently opposed (Renouf, 1999).

Another factor influencing the perception of the public is the availability of legislation on gene technology in a particular country. The fact that several countries, including South Africa, have legislation on this issue is a positive sign. This is beneficial to consumers and scientists, since it usually provides a clear framework within which to operate on these sensitive issues. The fact is that controlled experiments are the only way to answer some of the probing questions being asked about the potential risks of transgenic organisms (Skene, 1999; Smeaton, 1999).

\section{CONCLUSIONS}

The grapevine and wine industries are well established worldwide and are in the fortunate position of having considerable genetic resources available. Currently, however, the wine industry relies heavily on a few select traditional cultivars, partly because it seems to be hesitant to introduce new varietal names. This brings the industry to a crossroad regarding the global need to increase yield of healthy produce without the use of chemicals that are potentially harmful to both man and the environment.

In the past decade, genetic transformation and regeneration of transgenic grapevines have been realised, opening new possibilities for the improvement of this ancient and important genotype. The advances made in understanding the grapevine genome and identifying and classifying grapevine varieties and clones, together with the successes in transformation and regeneration of grapevine have resulted in innovative approaches to address current problems. It is now, for example, possible to tap into the vast resources of disease and abiotic resistance of the American spp. by incorporating only the beneficial traits into $V$. vinifera cultivars. The isolation and characterisation of increasing numbers of genes and promoters involved in specific processes in the 
grapevine, such as disease resistance and berry ripening, has clarified some aspects of these intricate processes. Similar studies conducted on the pathogens of grapevine, their infection of and interaction with the hosts, as well as their early and accurate detection, are stimulating new initiatives in the manipulation of grapevine diseases.

These examples highlight the need to integrate knowledge gained from different approaches. Only with the integration of the vast existing, ever-increasing knowledge base on viticulture and the new technologies of genetic manipulation will the true potential of the technology be realised. It should not be a replacement strategy, but a value-adding approach. Central to these issues, however, is the need to consolidate as scientists, global industries and consumers on the pressing and highly controversial issues of intellectual property rights, the naming of transgenic vines, and the handling of the debate and analyses of genetically modified organisms.

\section{LITERATURE CITED}

ABDALLAH, F.B., CHIBANI, F., FNAYOU, A., GHORBEL, A. \& BOUR SIQUOT, J.M., 1998. Biochemical characterization of Tunisian grapevine varieties. J. Int. Sci. Vigne Vin 32, 17-25.

ABU-GOUKH, A.A., GREVE, L.C. \& LABAVITCH, J.M., 1983. Purification and partial characterization of "Bartlett" pear fruit polygalacturonase inhibitors. Physiol. Plant Pathol. 23, 111-122.

AGEORGES, A., ISSALY, N., PICAUD, S., DELROT, S. \& ROMIEU, C., 2000. Plant Physiol. Biochem. (in press).

AGRIOS, G.N., 1997. In: Plant Pathology. Academic press, San Diego.

ALLEWELDT, G., 1988. The genetic resources of Vitis: Genetic and geographic origin of grape cultivars, their prime name and synonyms. In: Bundesforschungsanstalt für Rebenzüchtung, Siebeldingen.

ALLEWELDT, G. \& KOCH, R., 1977. Der Athylengehalt reifender Weinbeeren. Vitis 16, 263, 271.

ALTMAN, A., 1999. Plant biotechnology in the $21^{\text {st }}$ century: The challenges ahead. EJB 2, 51-55.

ALTAMURA, M.M., CERSOSIMO, A., MAJOLI, C. \& CRESPAN, M., 1992. Histological study of embryogenesis and organogenesis from anthers of Vitis rupestris du Lot cultured in vitro. Protoplasma 171, 134-141.

ANTCLIFF, A.J., 1992. Taxonomy- The grapevine as a member of the plant kingdom. In: COOMBE, B.G. \& DRY, P.R. (eds). Viticulture, vol. 1. Winetitles, Underdale. pp. 107-118.

ATANASSOVA, R., LETERRIER, M., LAQUITAINE, L., PICAUD, S., GAILLARD, C., COUTOS-THÉVENOT, P. \& DELROT, S., 2000. Functional analysis of a hexose transporter expressed during grape berry ripening. $6^{\text {th }}$ International Symposium on Grapevine Physiology and Biotechnology, Greece.

BAILEY, L.H., 1933. The species of grapes peculiar to North America. Gentes Herbarum 3, 150-244.

BARIBAULT, T.J., SKENE, K.G.M. \& SCOTT, N.S., 1989. Genetic transformation of grapevine cells. Plant Cell Rep. 8, 137-140.

BARIBAULT, T.J., SKENE, K.G.M. \& SCOTT, N.S., 1990. Transgenic grapevines: Regeneration of shoots expressing $\beta$-glucuronidase. J. Exp. Bot. 41, 1045-1049.

BARRETT, C., COBB, E., MCNICOL, R. \& LYON, G., 1997. A risk assessment study of plant genetic transformation using Agrobacterium and implications for analysis of transgenic plants. Plant Cell Tiss. Org. Cult. 47, 135-144.

BECK, D.I., VAN DOLLEWEERD, C.J., LOUGH, T.J.. BALMORI, E., VOOT, D.M. \& ANDERSEN, M.T., 1994. Disruption of virus movement confers broadspectrum resistance against systemic infection by plant viruses with a triple gene block. Proc. Natl. Acad. Sci. USA 91, 10310-10314.

BERRES, R., OTTEN, L., TINLAND, B., MALGARINI-CLOG, E. \& WALTER, B., 1992. Transformation of Vitis tissue by different strains of Agrobacterium tumefaciens containing the T-6B gene. Plant Cell Rep. 11, 192-195.

BIRCH, R.G., 1997. Plant transformation: Problems and strategies for practical application. Annu. Rev. Plant Physiol. Mol. Biol. 48, 297-326.

BIZILY, S.C., RUGH, C. \& MEAGHER, R.B., 2000. Phytodetoxification of hazardous organomercurials by genetically engineered plants. Nat. Biotechnol. 18, 213-217.
BORNHOFF, B.-A., HARST, M., ZYPRIAN, E. \& TÖPFER, R., 2000. Agrobacterium tumefaciens-mediated genetic transformation and regeneration of different explants of Vitis vinifera. $6^{\text {th }}$ International Symposium on Grapevine Physiology and Biotechnology, Greece.

BOSS, P.K., DAVIES, C. \& ROBINSON, S.P., 1996a. Analysis of the expression of anthocyanin pathway genes in developing Vitis vinifera $\mathrm{L}$. cv. Shiraz grape berries and the implications for pathway regulation. Plant Physiol. 111, 10591066.

BOSS, P.K., DAVIES, C. \& ROBINSON, S.P., 1996b. Expression of anthocyanin biosynthesis pathway genes in red and white grapes. Plant Mol. Biol. 32, 565-569. BOSS, P.K., DAVIES, C. \& ROBINSON, S.P., 1996c. Anthocyanin composition and anthocyanin pathway gene expression in grapevine sports differing in berry skin colour. Aust. J. Grape Wine Res. 2, 163-170.

BOUQUET, A., 1989. Intérèt des techniques de culture in vitro pour l'amélioration génétique de la vigne. Bull. L'OIV 697-698, 179-192.

BOUQUET, A., PIGANEAU, B. \& LAMAISON, A.M., 1982. Influence du génotype sur la production de cals, d'embryoides et de plantes entiéres par culture d' anthéres in vitro dans le genre Vitis. Compte Rendue de l' Académie des Sciences de Paris 295, 569-574.

BOWERS, J., BOURSIQUOT, J.M., THIS, P., CHU, K., JOHANSSON, H. \& MEREDITH, C., 1999. Historical genetics: The parentage of Chardonnay, Gamay and other wine grapes of Northeastern France. Science 285, 1562-1565.

BOWERS, J.E. \& MEREDITH, C.P., 1997. The parentage of a classic wine grape, Cabernet sauvignon. Nat. Gen. 16, 84-87.

BRAY, E.A., 1997. Plant responses to water deficit. Trends Plant Sci. 2, 48-54. BROWN, A.E. \& ADIKARAM, N.K.B., 1982. The differential inhibition of pectic enzymes from Glomerella cinulata and Botrytis cinerea by a cell wall protein from Capsicum annuum fruit. Phytopathol. 105, 27-38.

BROWN, G., 1999. Experiences in the development and commercialisation of gene technology products in the United Kingdom food industry. In: BLAIR, R.J., SAS, A.N., HAYS, P.F. \& HØJ, P.B. (eds). Proceedings of the $10^{\text {th }}$ Australian Wine Industry Technical Conference, pp. 160-161.

BRUNKE, K.J. \& MEEUSEN, R.L., 1991. Insect control with genetically engineered crops. Trends Biotechnol. 9, 197-200.

BUSAM, G., KASSEMEYER, H-H. \& MATERN, U., 1997. Differential expression of chitinases in Vitis vinifera L. responding to systemic acquired resistance activators or fungal challenge. Plant Physiol. 115, 1029-1038.

CALDERON, A.A., ZAPATA, J.M., MUNOZ, R. \& BARCELO, A.R., 1994 Peroxidase-mediated formation of resveratrol oxidation products during the hypersensitive-like reaction of grapevine cells to an elicitor from Trichoderma viside. Physiol. Mol. Plant Pathol. 44, 289-299.

CALDERON, A.A., ZAPATA, J.M., MUNOZ, R., PEDRENO, M.A. \& BARCELO, A.R., 1993. Resveratrol production as part of the hypersensitive-like response of grapevine cells to an elicitor from Trichoderma viside. New Phytol. 124, 455463.

CAMMUE, B., THEVISSEN, K., HENDRIKS, M., EGGERMONT, K. GODERIS, I., PROOST, P., VAN DAMME, J., OSBORN, R., GUERBETTE, F., KADER, J. \& BROEKAERT, W., 1995. A potent antimicrobial protein from onion seeds showing sequence homology to plant lipid transfer proteins. Plant Physiol. 109, 445-455.

CARBONNEAU, A., 1983. Stèrilitès mâle et femalle dans le genre Vitis. II. Consèquences en gènètique et sèlection. Agronomie 3, 645-649.

CARREÑO, J., ALMELA, L., MARTÍNEZ, A. \& FERNÁNDEZ-LÓPEZ, J.A., 1997. Chemotaxonomical classification of red table grapes based on anthocyanin profile and external colour. Lebensm.-Wiss. U.-Technol. 30, 259-265.

CAVAN, G., BISS, P. \& MOSS, S.R., 1998. Herbicide resistance and gene flow in wild-oats (Avena fatua and Avena sterilis spp. ludoviciana). Ann. Appl. Biol. 133, 207-217.

CAWTHON, D.L. \& MORRIS, J.R., 1982. Relationship of seed number and maturity to berry development, fruit maturation, hormonal changes, and uneven ripening of 'Concord' (Vitis labrusca L.) grapes. J. Am. Soc. Hortic. Sci. 107, 1097-1104.

CERVONE, F., DE LORENZO, G., DEGRÀ, L. \& SALVI, G., 1986. Interactions of fungal polygalacturonase with plant proteins in relation to specificity and regulation of plant defence response. In: OLUGTENBURG, B. (ed). Recognition in Microbe-Plant Symbiotic and Plant Pathogenic Interactions, NATO ASI Series, vol. H4. Springer-Verlag, Berlin. pp. 253-258.

CERVONE, F., DE LORENZO, G., DEGRÀ, L., SALVI, G. \& BERGAMI, M., 1987. Purification and characterisation of a polygalacturonase-inhibiting protein from Phaseolus vulgaris L. Plant Physiol. 85, 631-637. 
CHAMBERLAIN, D. \& STEWART, C.N., 1999. Transgene escapes and transplastomics. Nat. Biotechnol. 17, 330-331.

CHENG, J., BOLYARDM, M.G., SAXWMA, R.C. \& STICKLEN, M.B., 1992. Production of insect resistant potato by genetic transformation with a $\alpha$-endotoxin from Bacillus thuringiensis var. kurstaki. Plant Sci. 81, 83-91.

COLBY, S.M. \& MEREDITH, C.P., 1990. Kanamycin sensitivity of cultured tissues of Vitis. Plant Cell Rep. 9, 237-240.

COLBY, S.M., JUNCOSA, A.M. \& MEREDITH, C.P., 1991. Cellular differences in Agrobacterium susceptibility and regeneration capacity restrict the development of transgenic grapevines. J. Am. Soc. Hort. Sci. 116, 356-361.

COLOVA-TSOLOVA, V., FARCHI, S.H., EVEN, S., SAHAR, N., GOLLOP, R. $\&$ PERL, A., 2000. Co-transformation with two vectors and regeneration of transgenic plants on the basis of high efficient Agrobacterium-mediated gene transfer in grape embryogenic cell suspension. $6^{\text {th }}$ International Symposium on Grapevine Physiology and Biotechnology, Greece.

COOMBE, B.G. \& HALE, C.R., 1973. The hormone content of ripening grape berries and the effects of growth substance treatments. Plant Physiol. 51, 629-634. COOMBE, B.G., 1992. Research on development and ripening of the grape berry. Am. J. Enol. Vitic. 43, 101-110.

COSTACURTA, A., CALÒ, R., CARRARO, A., GIUST, M. ANTONIAZZI, M. \& LAZZARO, G., 1996a. Computer-aided methods for the characterization of varieties. Riv. Vitic. Enol. 492, 27-33.

COSTACURTA, A., CRESPAN, M. \& MILANI, N., 1996b. Varietal and clonal characterization experiences by means of molecular markers in Vitis vinifera $\mathrm{L}$. Riv. Vitic. Enol. 49, 35-40.

COUTOS-THÉVENOT, P., GOEBEL-TOURAND, I., MAURO, M.C., JOUANNEAU, J.P., BOULAY, M., DELOIRE, A. \& GUERN, J., 1992a. Somatic embryogenesis from grapevine cells. I- Improvement of embryo development by changes in culture conditions. Plant Cell Tiss. Org. Cult. 29, 125-133.

COUTOS-THÉVENOT, P., JOUENNE, T., MAES, O., GUERBETTE, F., GROSBOIS, M., LE CAER, J.P., BOULAY, M., DELOIRE, A., KADER, J.C. \& GUERN, J., 1993. Four 9-kDa proteins excreted by somatic embryos of grapevine are isoforms of lipid-transfer proteins. Eur. J. Biochem. 217, 885-889.

COUTOS-THÉVENOT, P., MAES, O., JOUENNE, T., MAURO, M.C., BOULAY, M., DELOIRE, A. \& GUERN, J., 1992b. Extracellular protein patterns of grapevine cell suspensions in embryogenic and non-embryogenic situations. Plant Sci. 86, 137-145.

CROUCH, M.L., 1992. Non-zygotic embryos of Brassica napus L. contain embryo-specific storage proteins. Planta 156, 520-524.

DAVIES, C., BOSS, P.K. \& ROBINSON, S.P., 1997. Treatment of grape berries, a nonclimacteric fruit with a synthetic auxin, retards ripening and alters the expression of developmentally regulated genes. Plant Physiol. 115, 1155-1161.

DAVIES, C. \& ROBINSON, S.P., 1996. Sugar accumulation in grape berries Cloning of two putative vacuolar invertase cDNAs and their expression in grapevine tissues. Plant Physiol. 111, 275-283.

DAVIES, C. \& ROBINSON, S.P., 2000a. Differential screening indicates a dramatic change in mRNA profiles during grape berry ripening. Cloning and characterization of cDNAs encoding putative cell wall and stress response proteins. Plant Physiol. 122, 803-812.

DAVIES, C. \& ROBINSON, S.P., 2000b. Molecular biology of grape berry development. $6^{\text {th }}$ International Symposium on Grapevine Physiology and Biotechnology, Greece.

DE BLOCK, M., HERRERA-ESTRELLA, L., VAN MONTAGU, M., SCHELL, J. \& ZAMBRYSKI, P., 1984. Expression of foreign genes in regenerated plants and their progeny. EMBO J. 3, 1681-1689.

DELANNAY, X., LA VALLEE, B.J., PROKSCH, R.K., FUCHS, R.L., SIMS, S.R., GREENPLATE, J.T., MARRONE, P.G., DODSON, R.B., AUGUSTINE, J.J., LAYTON, J.G. \& FISCHHOFF, D.A., 1989. Field performance of transgenic tomato plants expressing the Bacillus thuringiensis var. kurstaki insect control protein. BioTechnol. 7, 1265-1269.

DENG, W.Y., PU, X.A., GOODMAN, R.N., GORDON, M.P. \& NESTER, E.W. 1995. T-DNA genes responsible for inducing a necrotic response on grapevines. Mol. Plant Microbe Interact. 8, 538-548.

DERCKEL, J-P., LEGENDRE, L., AUDRAN, J-C., HAYE, B. \& LAMBERT, B., 1996. Chitinases of the grapevine (Vitis vinifera L.): Five isoforms induced in leaves by salicylic acid are constitutively expressed in other tissues. Plant Sci. 119, 31-37.

DIJAK, M., SMITH, D.L., WILSON, T.J. \& BROWN, D.C.W., 1986. Stimulation of direct embryogenesis from mesophyll protoplasts of Medicago sativa. Plant Cell Rep. 5, 468-470.
DODEMAN, V.L., DUCREUX, G. \& KREIS, M., 1997. Zygotic embryogenesis versus somatic embryogenesis. J. Exp. Bot. 48, 1493-1509.

EIBACH, R., 1999. Development of grape cultivars - Perspectives for the future. OIV Technical Presentation.

EIRAS-DIAS, J.E. \& BRUNO-SOUSA, R., 1998. Isoenzymatic polymorphism differentiation of Portuguese grapevine cultivars. Am. J. Enol. Vitic. 49, 86-90.

EIRAS-DIAS, J.E. GALVÃO, N. \& PALUDETTI, G., 1996. The glucosephosphate isomerase and the phosphoglucomutase as isozyme markers of some Portuguese grapevine cultivars. Riv. Vitic. Enol. 49, 35-40.

ESTERHUIZEN, R., VIVIER, M.A., BOTHA, F.C. \& PRETORIUS, I.S., 2000. Transformation of grapevine (Vitis vinifera) with a yeast-derived invertase (SUC2) targeted to different cellular localizations. $16^{\text {th }}$ South African Society of Biochemistry and Molecular Biology. BIOY2K Combined Millennium Meeting, Grahamstown.

FARIA, M.A., MAGALHAES, R., FERREIRA, M.A., MEREDITH, C.P. \& MONTEIRO, F.F., 2000. Vitis vinifera must varietal authentication using microsatellite DNA analysis (SSR). J. Agric. Food Chem. 48, 1096-1100.

FAURE, O., 1990. Embryons somatiques de Vitis rupestris et embryons zygotiques de Vitis sp.: Morphologie, histologie, histochimie et dévelppement. Can.J. Bot. 68, 2305-2315.

FAURE, O. \& AARROUF, J., 1994. Metabolism of reserve products during development of somatic embryos and germination of zygotic embryos in grapevine. Plant Sci. 96, 167-178.

FAURE, O., AARROUF, J. \& NOUGAREDE, A., 1996a. Ontogenesis, differentiation and precocious germination in anther-derived somatic embryos of grapevine (Vitis vinifera L.): Embryogenic organogenesis. Ann. Bot. 78, 29-35.

FAURE, O., AARROUF, J. \& NOUGAREDE, A., 1996b. Ontogenesis, differentiation and precocious germination in anther-derived somatic embryos of grapevine (Vitis vinifera L.): Proembryogenesis. Ann. Bot. 78, 23-28.

FAVARON, D., D'OVIDIO, R., PORCEDDU, E. \& ALGHISI, P., 1994. Purification and molecular characterization of a soybean polygalacturonaseinhibiting protein. Planta 195, 80-87.

FENGQIN, Z., FANGMEI, L. \& DABIN, G., 1990. Studies on germplasm resources of wild grape species (Vitis spp.) in China. In: Proceedings of the 5th International Symposium of Grape Breeding. pp. 50-57.

FILLION, L., AGEORGES, A., PICAUD, S., COUTOS-THÉVENOT, P., LEMOINE, R., ROMIEU, C. \& DELROT, S., 1999. Cloning and expression of a hexose transporter during the ripening of grape berry. Plant Physiol. 120, 10831093.

FISCHHOFF, D.A., BOWDISH, K.S., PERLAK, F.J., MARRONE, P.G., MCCORMICK, S.M., NIEDERMEYER, J.G., DEAN, D.A., KUNSANOKRETZER, K., MAYER, E.J., ROCHESTER, D.E., ROGERS, S.G. \& FRALEY, R.T., 1987. Insect tolerant tomato plants. BioTechnol. 5, 807-813.

FRANCK-OBERASPACH, S.L. \& KELLER, B., 1997. Consequences of classical and biotechnological resistance breeding for food toxicology and allergenicity. Plant Breed. 116, 1-17.

FRANKS T., HE, D.G. \& THOMAS, M., 1998. Regeneration of transgenic Vitis vinifera L. Sultana plants: Genotypic and phenotypic analysis. Mol. Breeding 4, 321-333.

GASKELL, G., BAUER, M.W., DURANT, J. \& ALLUM, N.C., 1999. Worlds apart? The reception of genetically modified foods in Europe and the US. Science 285, 384-387.

GIANNAKIS, C., BUCHELI, C.S., SKENE, K.G.M., ROBINSON, S.P. \& SCOTT, N.S., 1998. Chitinase and $\beta$-1,3-glucanase in grapevine leaves: a possible defence against powdery mildew infection. Aust. J. Grape Wine Res. 4, 14-22. GÖLLES, R., DA CÂMARA MACHADO, A., MINAFRA, A., GRIBAUDO, I., SAVINO, V., SALDARELLI, G., MARTELLI, G.P., KATINGER, H. \& LAIMER DA CÂMARA MACHADO, M., 2000. Fighting grapevine fanleaf disease and the ruggose wood complex by transgenic expression of viral sequences. $6^{\text {th }}$ International Symposium on Grapevine Physiology and Biotechnology, Greece.

GOUSSARD, P.G. \& WIID, J., 1992. The elimination of fanleaf virus from grapevines using in vitro somatic embryogenesis combined with heat therapy. $S$. Afr. J. Enol. Vitic. 13, 81-83.

GRANDO, M.S. \& FRISINGHELLI, C., 1998. Grape microsatellite markers: Sizing of DNA alleles and genotype analysis of some grapevine cultivars. Vitis 37, 79-82.

GRAY, D.J. \& MEREDITH, C.P., 1992. The Grape. In: HAMMERSCLAG, F. \& LITZ, R.E. (eds). Biotechnology in Agriculture: Biotechnology of perennial fruit crops, vol. 8. CAB International, Wallingford. pp. 229-264. 
GRAY, D.J. \& MORTENSEN, J.A., 1987. Initiation and maintenance of long term somatic embryogenesis from anthers and ovaries of Vitis longii microsperma. Plant Cell Tiss. Org. Cult. 9, 73-80.

HALE, C.R. \& COOMBE, B.G., 1974. Abscisic acid - an effect on the ripening of grapes. Bull. R. Soc. NZ 12, 831-836.

HALPERIN, W., 1966. Alternative morphogenetic events in cell suspensions. Am. J. Bot. 53, 443-453.

HARTMANN, H.T., KESTER, D.E. \& DAVIES, F.T., 1990. General aspects of propagation. In: Plant propagation: Principles and practices. Prentice-Hall, New Jersey. pp. 1-14.

HAWKER, J.S., 1969. Changes in the activities of enzymes concerned with sugar metabolism during the development of grape berries. Phytochem. 8, 9-17.

HÉBERT, D., KIKKERT, J.R., SMITH, F.D. \& REISCH, B.I., 1993. Optimization of biolistic transformation of embryogenic grape cell suspensions. Plant Cell Rep. 13, 405-409.

HÉBERT-SOULÉ, D., KIKKERT, J.K. \& REISCH, B.I., 1995. Phosphinothricin stimulates somatic embryogenesis in grape (Vitis sp. L.). Plant Cell. Rep. 14, 380384.

HEMENWAY, C., TUMER, N.E., POWELL, P.A. \& BEACHY, R.N., 1989. Genetic engineering of plants for viral disease resistance. In: SCHELL, J. \& VASIL, I.K. (eds). Cell culture and somatic cell genetics of plants: Molecular Biology of plant nuclear genes. Academic Press, San Diego. pp. 406-423.

HILL, K.K., JARVIS-EAGAN, N., HALK, E.L., KRAHN, K.J., LIAO, L.W., MATHEWSON, R.S., MERLO, D.J., NELSON, S.E., RASHKA, K.E. \& LOESCH-FRIES, L.S., 1991. The development of virus-resistant alfalfa, Medicago sativa L. BioTechnol. 9, 373-377.

HOOYKAAS, P.J.J. \& SCHILPEROORT, R., 1992. Agrobacterium and plant engineering. Plant Mol. Biol. 19, 15-38.

HUNG, X.S. \& MULLINS, M.G., 1989. Application of biotechnology to transferring alien genes to grapevine. Hereditas 11, 9-11.

JACH, G., GÖRNHARDT, B., MUNDY, J., LOGEMANN, J., PINSDORF, E., LEAH, R., SCHELL, J. \& MAAS, C., 1995. Enhanced quantitative resistance against fungal disease by combinatorial expression of different barley antifungal proteins in transgenic tobacco. Plant J. 8, 97-109.

JACKSON, R.S., 1994. Grapevine species and varieties. In: Wine Science: Principles and application. Academic Press. San Diego. pp. 11-31.

JONGEDIJK, E., DE SCHUTTER, A.A.J.M., STOLTE, T., VAN DEN ELZEN, P.J.M. \& CORNELISSEN, B.J.C. 1992. Increased resistance to potato virus $X$ and preservation of cultivar properties in transgenic potato under field conditions. BioTechnol. 10, 422-429.

JONGEDIJK, E., TIGELAAR, H., VAN ROEKEL, J.S.C., BRE-VLOEMANS, S.A., DEKKER, I., VAN DEN ELZEN. P.J.M., CORNELISSEN, B.J.C. \& MELCHERS, L.S., 1995. Synergistic activity of chitinases and $\beta-1,3$-glucanases enhances fungal resistance in transgenic tomato plants. Euphytica 85, 173-180.

JOUBERT, D.A., VIVIER, M.A. \& PRETORIUS, I.S., 2000. Agrobacterium vitis derived grapevine transformation system: T-DNA characterisation of an indigenous A. vitis strain. $11^{\text {th }}$ Biennial Congress of the South African Society for Microbiology. BIOY2K Combined Millennium Meeting, Grahamstown.

KIKKERT, J.R., ALI, G.S., STRIEM, M.J., MARTENS, M.H., WALLACE, P.G., MOLINO, L. \& REISCH, B.I. 1996. Genetic engineering of grapevine (Vitis sp.) for enhancement of disease resistance. In: Proceedings of the $3^{\text {rd }}$ International Symposium on In Vitro Horticulture and Breeding, Jerusalem.

KIKKERT, J.R., ALI, G.S., WALLACE, P.G., REUSTLE, G.M. \& REISCH, B.I., 2000. Expression of a fungal chitinase in Vitis vinifera L. Merlot and Chardonnay plants produced by biolistic transformation. In: BOUQUET, A. \& BOURSIQUOT, J.M. (eds). Proceedings of the International Symposium on Grapevine Genetics and Breeding, ISHS, vol. I, Acta Hort. 528, 297-303.

KIKKERT, J.R. \& REISCH, B.I., 1996. Genetic engineering of grapevines for improved disease resistance. Grape Res. News 7, 4-5.

KLEIN, T.M., WOLF, E.D., WU, R. \& SANFORD, J.C., 1987. High-velocity microprojectiles for delivering nucleic acids into living cells. Nature 327, 70-73.

KLING, J., 1996. Could transgenic supercrops one day breed superweeds? Science 274, 180-181.

KRASTANOVA, S., PERRIN, M., BARBIER, P., DEMANGEAT, G., CORNUET, P., BARDONNET, N., OTTEN, L., PINCK, L. \& WALTER, B., 1995. Transformation of grapevine rootstock with the coat protein gene of grapevine fanleaf nepovirus. Plant Cell Rep. 14, 550-554.

KRUL, W.R. \& WORLEY, J.F., 1977. Formation of adventitious embryos in callus cultures of "Seyval", a French hybrid grape. J Am. Soc. Hort. Sci. 102, 360363.
LE-GALL, O., TORREGROSA, L., DANGLOT, Y., CANDRESSE, T. \& BOUQUET, A., 1994. Agrobacterium-mediated genetic transformation of grapevine somatic embryos and regeneration of transgenic plants expressing the coat protein of grapevine chrome mosaic nepovirus (GCMV). Plant Sci. 102, 161-170.

LECKIE, F., MATTEI, B., CAPODICASA, C., HEMMINGS, A., NUSS, L., ARACRI, B., DE LORENZO, G. \& CERVONE, F., 1999. The specificity of polygalacturonase-inhibiting protein (PGIP): A single amino acid substitution in the solvent-exposed $\beta$-strand/ $\beta$-turn region of the leucine-rich repeats (LRRs) confers a new recognition capability. EMBO J. 18, 2352-2363.

LEE, W.S., TZEN, J.T.C., KRIDL, J.C., RADKE, S.E. \& HUANG, A.H., 1991 Maize oleosin is correctly targeted to seed oil bodies in Brassica napus transformed with the maize oleosin gene. Proc. Natl. Acad. Sci. USA 88, 6181-6185. LEVADOUX, L., 1956. Les populations auvages et cultivées de Vitis vinifera L. Ann. Amelior. Plant. 1, 59-118.

LIU, C.M., XU, Z.H. \& CHUA, N.H., 1993. Auxin polar transport is essential for the establishment of bilateral symmetry during early plant embryogenesis. Plant Cell 5, 621-630.

MAES, O., COUTOS-THÉVENOT, P., JOUENNE, T., BOULAY, M. \& GUERN, J. 1997. Influence of extracellular proteins, proteases and protease inhibitors on grapevine somatic embryogenesis. Plant Cell Tiss. Org. Cult. 50, 97-105.

MANCUSO, S., PISANI, P.L., BANDINELLI, R. \& RINALDELLI, E., 1998. Application of an artificial neural network (ANN) for the identification of grapevine genotypes. Vitis 37, 27-32.

MARTELLI, G.P., 1993. Graft-transmissible diseases of grapevines. In. Handbook for detection and diagnosis. FAO Publication Division, Rome.

MARTELLI, G.P., 1999. The impact of propagation material on vine health - a European perspective. In: BLAIR, R.J., SAS, A.N., HAYS, P.F. \& HØJ, P.B. (eds). Proceedings of the $10^{\text {th }}$ Australian Wine Industry Technical Conference. pp. 197207.

MARTINELLI, L., 1995. Riflessioni sulle prospettive di introduzione di tecniche molecolari nel miglioramento genetico dell vite. Riv. Fruitticol. 5, 71-74.

MARTINELli, L., BRAGAGNA, P., POLETTI, V. \& SCIENZA, A., 1993. Somatic embryogenesis from leaf- and petiole-derived callus of Vitis rupestris. Plant Cell Rep. 12, 207-210.

MARTINELLI, L., BUZKAN, N., MINAFRA, A., SALDARELLI, P., COSTA, D., POLETTI, V., FESTI, S., PERL, A. \& MARTELLI, G.P., 2000a. Genetic transformation of tobacco and grapevines for resistance to viruses related to the rugose wood disease complex. In: BOUQUET, A. \& BOURSIQUOT, J.M. (eds). Proceedings of the International Symposium on Grapevine Genetics and Breeding, ISHS, vol. I, Acta Hort. 528, 321-327.

MARTINELLI, L., CANDIOLI, E., VECCHIA, F.D., MINAFRA, A. \& RASCIO, N., 2000b. Expression of the movement protein gene of the grapevine Vitivirus $A$ in transgenic grapevines and physiology of the regenerants. $6^{\text {th }}$ International Symposium on Grapevine Physiology and Biotechnology, Greece.

MARTINELLI, L. \& MANDOLINO, G., 1994. Genetic transformation and regeneration of transgenic plants in grapevine (Vitis rupestris S.) Theor. Appl. Gen. 88, 621-628.

MARTINELLI, L. \& MANDOLINO, G., 1996. A study on the insertion efficiency of an exogenous gene in a RO population of grape (Vitis rupestris S.). S. Afr. J. Enol. Vitic. 17, 27-30.

MARTINELLI, L. \& MANDOLINO, G., 2000. Genetic transformation in Vitis. In: BAJAJ, Y.P.S. (ed). Biotechnology in Agriculture and Forestry, Transgenic crops II, Springer-Verlag, Berlin, vol. 47 (in press).

MAURO, M.C., COUTOS-THÉVENOT, P. \& BOULAY, M., 1995a. Somatic embryogenesis of grape: support for genetic transformation. $7^{\text {th }}$ European Congress on Biotechnology, Nice.

MAURO, M.C., NEF, C. \& FALLOT, J., 1986. Stimulation of somatic embryogenesis and plant regeneration from anther culture of Vitis vinifera cultivar Cabernet Sauvignon. Plant Cell Rep. 5, 377-380.

MAURO, M.C., TOUTAIN, S., WALTER, B., PINCK, L., OTTEN, L., COUTOS-THÉVENOT, P., DELOIRE, A. \& BARBIER, P., 1995b. High efficiency regeneration of grapevine plants transformed with the GFLV coat protein gene. Plant Sci. 112, 97-106.

MELCHIOR, F. \& KINDL, H., 1991. Coordinate- and elicitor-dependent expression of stilbene synthase and phenylalanine ammonia-lyase genes in Vitis cv. Optima. Arch. Biochem. Biophys. 288, 552-557.

MEREDITH, C., 1999. Economic and legal considerations related to the development and use of transgenic grapevines. OIV Day of Reflection on Genetically Modified Organisms, Paris. 
MINAFRA, A., GÖLLES, R., DA CAMAMRA MACHADO, A., SALDARELLI, P., SAVINO, V. \& KATINGER, H., 1997. Coat protein-mediated resistance against grapevine virus A and grapevine virus B in Nicotiana benthamiana and Nicotiana occidentalis. $12^{\text {th }}$ Meeting ICVC, Lisbon.

MINCK, G.I., WAMPLE, R. \& HOWLL, W.E., 1998. Heat treatment of perennial plants to eliminate phytoplasmas, viruses and viroids, while maintaining plant survival. In: HADIDI, A., KETARPAL, P.K. \& KOGANEZAWA, H. (eds). Plant Virus Disease Control. Am. Phytopathol. Soc. Press, St. Paul. pp. 332-345.

MODHORST, A.P., TOONEN, M.A.J., DE VRIES, S., 1997. Plant embryogenesis. Plant Sci. 16, 535-576.

MULLINS, M.G., BOUQUET, A. \& WILLIAMS, L.E., 1992. In: Biology of the grapevine. Cambridge Univ. Press, Cambridge.

MULLINS, M.G. \& SRINIVASAN, C., 1976. Somatic embryos and plantlets from an ancient clone of the grapevine (cultivar Cabernet sauvignon) by apomixis in vitro. J. Exp. Bot. 27, 1022-1030.

MULLINS, M.G., TANG, F.C.A. \& FACCIOTI, D., 1990. Agrobacterium mediated genetic transformation of grapevines: Transgenic plants of Vitis rupestris Scheele and buds of Vitis vinifera L. BioTechnol. 8, 1041-1045.

MURPHY, D.J., 1992. Modifying oilseed crops for non-edible products. Trends Biotechnol. 10, 84-87.

NAKANO, M., HOSHINO, Y. \& MII, M., 1994. Regeneration of transgenic plants of grapevine (Vitis vinifera L.) via Agrobacterium rhizogenes-mediated transformation of embryogenic calli. J. Exp. Bot. 45, 649-656.

NEGRUL, A.M., 1938. Evolucija Kuljturnyx from vinograda. C. R. Acad. Sci. URSS 18, 585-588.

NÚÑEZ, D.R. \& WALKER, M.J., 1989. A review of palaeobotanical findings of early Vitis in the Mediterranean and of the origins of cultivated grapevines, with special reference to prehistoric exploitations in the western Mediterranean. Rev. Paleobot. Palynol. 61, 205-237.

OLIEN, W.C., 1990. The muscadine grape: Botany, viticulture, history and current industry. Hortscience 25, 732-739.

OLLAT, N., POIZAT, C., LIMA DA SILVA, A. \& DOAZAN, J.P., 2000. Quantitative rootstock-scion relationships in grapevine: Investigation by the analysis of reciprocal micrograftings. $6^{\text {th }}$ International Symposium on Grapevine Physiology and Biotechnology, Greece.

OPHELL, K. \& KERR, K., 1990. Agrobacterium vitis sp. nov. for strains of Agrobacterium biovar 3 from grapevine. Int. J. Syst. Bacteriol. 40, 236-241.

OPPENHEIM, A.B. \& CHET, I., 1992. Cloned chitinases in fungal plantpathogen control strategies. TIBTECH 10, 392-394.

OSBORN, R., DE SAMBLANX, G., THEVISSEN, K., GODERIS, I., TORREKENS, S., VAN LEUVEN, F., ATTENBOROUGH, S., REES, S. \& BROEKAERT, W., 1995. Isolation and characterisation of piant defensins from seeds of Asteraceae, Fabaceae, Hippocastanaceae and Saxifragaceae. FEBS Lett. 368, 257-262.

PAULUS, F., CANADA, J. \& OTTEN, L., 1991. Limited host range Ti-plasmids: Recent origin form wide host range Ti-plasmids and involvement of a novel IS element, IS868. Mol. Plant Microbe Interact. 4, 190-197.

PERL, A. \& ESHDAT, Y., 1998. DNA transfer and gene expression in trangenic grapes. In: TOMBS, M.P. (ed). Biotechnology and genetic engineering reviews, vol. 15. Intercept Ltd. Andover, pp. 365-389.

PERL, A., GOLLOP, R., LIPSKY, A., SAHAR, N., HOLLAND, D., OR, E. \& ELYASI, R., 1996a. Regeneration and transformation of grape (Vitis vinifera $\mathrm{L}$.). Plant Tissue Cult. Biotechnol. 2, 187-193.

PERL, A., LOTAN, O., ABU-AMED, M. \& HOLLAND, D., $1996 \mathrm{~b}$. Establishment of an Agrobacterium-mediated genetic transformation system for grape (Vitis vinifera $\mathrm{L}$.): The role of antioxidants during grape-Agrobacterium interaction. Nat. Biotechnol. 14, 624-628.

PERL, A., SAAD, S., SAHAR, N. \& HOLLAND, D., 1995. Establishment of long term embryogenic cultures of seedless Vitis vinifera cultivars: Synergistic effect of auxins and the role of abscisic acid. Plant Sci. 104, 193-200.

PERL, A., SAHAR, N., FARCHI, S.H., COLOVA-TSOLOVA, V., HOLLAND, D. \& GOLLOP, R.. 2000. Conventional and biotechnological breeding of seedless table grapes in Israel. $6^{\text {th }}$ International Symposium on Grapevine Physiology and Biotechnology, Greece.

PERLAK, F.J., DEATON, R.W., ARMSTRONG, T.A., FUCHS, R.L., SIMS, S.R., GREENPLATE, J.T. \& FISCHHOFF, D.A., 1990. Insect resistant cotton plants. BioTechnol. 8, 939-943.

POLKINGHORNE, J.C., 2000. Ethical issues in biotechnology. TIBTECH 18, 810.

PONGRÁCZ, D.P., 1978. In: Practical Viticulture. David Philip Publisher Ltd., Claremont.
POTRYKUS, I., 1990. Gene transfer to cereals: An assessment. BioTechnol. 8, 535-542.

POTRYKUS, I., 1991. Gene transfer to plants: Assessment of public approaches and results. Annu. Rev. Plant Physiol. 42, 205-225.

POWELL-ABEL, P., NELSON, R.S., DE, B., HOFFMANN, N., ROGERS, S.G., FRALEY, R.T. \& BEACHY, R.N., 1986. Delay of disease development in transgenic plants that express the tobacco mosaic virus coat protein gene. Science 232, 738-743.

PRETORIUS, I.S., 2000. Tailoring wine yeast for the new millennium. Yeast 16, 675-729.

PRINS, M. \& GOLDBACH, R., 1996. RNA-mediated virus resistance in transgenic plants. Arch. Virol. 141, 2259-2276.

PU, X. \& GOODMAN, R.N., 1992. Attachment of Agrobacteria to grape cells. Appl. Environ. Microbiol. 59, 2572-2577.

PU, X. \& GOODMAN, R.N., 1993. Induction of necrogenesis by Agrobacterium tumefaciens on grape explants. Physiol. Mol. Plant Pathol. 41, 241-254.

RAJASEKARAN, K. \& MULLINS, M.G., 1979. Embryos and plantlets from cultured anthers of hybrid grapevines. J. Exp. Bot. 30, 399-407.

RAJASEKARAN, K. \& MULLINS, M.G., 1983a. The origins of embryos and plantlets from cultured anthers of hybrid grapevines. Am. J. Enol. Vitic. 34, 108113.

RAJASEKARAN, K. \& MULLINS, M.G., 1983b. Influence of genotype and sexexpression on formation of plantlets by cultured anthers of grapevines. Agronomie 3, 233-238.

RAMANATHAN, V., SIMPSON, C.G., THOW, G., IANETTA, P.P.M., MCNICOL, R.J. \& WILLIAMSON, B., 1997. cDNA cloning and expression of polygalacturonase-inhibiting proteins (PGIPs) from red raspberry (Rubus idaeus). $J$. Exp. Bot. 48, 1185-1193.

REGNER, F., STEINKELLNER, H., TURETSCHEK, E., STADLHUBER, A. \& GLÖSSL, J., 1996. Genetische characterisierung von reborten (Vitis vinifera) durch mikrosatelliten-analyse. Mitteilungen Klosterneuburg 46, 52-60.

RENOUF, C., 1999. Genetically modified foods - can we move from consumer reaction to consumer acceptance. In: BLAIR, R.J., SAS, A.N., HAYS, P.F. \& HØJ, P.B. (eds). Proceedings of the $10^{\text {th }}$ Austratian Wine Industry Technical Conference. pp. 156-157.

RIVES, M., 1975. Les orignes de la vigne. Recherche 53, 120-129.

ROBINSON, J., 1999. Ethics and transgenic crops: A review. EJB 2, 71-81.

ROBINSON, S.P., JACOBS, A.J. \& DRY, I.B., 1997. A class IV chitinase is highly expressed in grape berries during ripening. Plant Physiol. 114, 771-778.

ROBINSON, S.P., THOMAS, M., SCOTT, N.S., DRY, I., DAVIES, C., FRANKS, T., BOSS, P., HØJ \& VAN HEESWIJCK, R., 1999. Application of gene technology in viticulture. In: BLAIR, R.J., SAS, A.N., HAYS, P.F. \& HØJ, P.B. (eds). Proceedings of the $10^{\text {th }}$ Australian Wine Industry Technical Conference. pp. 134-138.

ROGERS, D.J. \& ROGERS, C.F., 1978. Systematics of North American grape species. Am. J. Enol. Vit. 29, 73-78.

ROYTCHEV, V., 1997. Palynological classification of seedless grape (Vitis vinifera L.) cultivars. Am. J. Enol. Vitic. 48, 207-213.

SALTZMAN, R.A., TIKHONOVA, I., BORDELON, B.P., HASEGAWA, P.M. \& BRESSAN, R.A., 1998. Coordinate accumulation of antifungal proteins and hexoses constitutes a developmentally controlled defence response during fruit ripening in grape. Plant Physiol. 117, 465-472.

SANFORD, J.C. \& JOHNSTON, S.A., 1985. The concept of parasite-derived resistance - deriving resistance genes from the parasite's own genome. J. Theor. Biol. 115, 395-405.

SANFORD, J.C., SMITH, F.D. \& RUSSEL, J.A., 1993. Optimizing the biolistic process for different biological applications. Methods Enzymol. 217, 483-509.

SCORZA, R., CORDTS, J.M., GRAY, D.J., GONSALVES, D., EMÉRSHAD, R.L. \& RAMMING, D.W., 1996. Producing transgenic "Thompson Seedless" grape (Vitis vinifera L.) plants. J. Am. Soc. Hort. Sci. 121, 616-619.

SCORZA, R., CORDTS, J.M., RAMMING, D.W. \& EMÉRSHAD, R.L., 1995. Transformation of grape (Vitis vinifera $\mathrm{L}$.) zygotic-derived somatic embryos and regeneration of transgenic plants. Plant Cell Rep. 14, 589-592.

SEFC, K., STEINKELLNER, H., WAGNER, H.W., GLÖSSL, J. \& FEGNER, F., 1997. Application of microsatellite markers to parentage studies in grapevine. Vitis 36, 179-183.

SEFC, K.M., GUGGENBERGER, S., REGNER, F., LEXER, C., GLÖSSL, J. \& STEINKELLNER, H., 1998a. Genetic analysis of grape berries and raisins using microsatellite markers. Vitis 37, 123-125. 
SEFC, K.M., REGNER, F., GLÖSSL, J. \& STEINKELLNER, H., 1998b. Genotyping of grapevine and rootstock cultivars using microsatellite markers. Vitis 37, 15-20

SENSI, E., VIGNANI, R., RHODE, W. \& BIRICOLTI, S., 1996. Characterization of genetic biodiversity with Vitis vinifera L. Sangiovese and Colorino genotypes by AFLP and ISTR DNA marker technology. Vitis 35, 183-188.

SEPPANEN, P., PUSKA, R., HONKANEN, J., TYULKINA, L.G., FEDORKIN, O., MOROZOV, S.Y.U. \& ATABEKOV, J.G., 1997. Movement protein-derived resistance to triple gene block-containing plant viruses. J. Gen. Virol. 78, 12411246.

SERAGELDIN, I., 1999. Biotechnology and food security in the $21^{\text {st }}$ century. Science 285, 387-389.

SHOEMAKER, R.C., CHRISTOFFERSON, S.E., GALBRAITH, D.W., 1987. Storage protein accumulation patterns in somatic embryos of cotton (Gossypium hirsutum L.). Plant Cell Rep. 6, 12-15.

SILVESTRONI, O., INTRIERI, C. \& DOMIZIO, N.D., 1996. Use of plyometric methods to determine some grapevine cultivars grown in Emilia Romagna. Riv. Vitic. Enol. 49, 17-26.

SKENE, L., 1999. Consumer concerns, what are they and are they being addressed? In: BLAIR, R.J., SAS, A.N., HAYS, P.F. \& HØJ, P.B. (eds). Proceedings of the $10^{\text {th }}$ Australian Wine Industry Technical Conference. pp. 153155.

SMEATON, J., 1999. Experiences in development and commercialisation of gene technology products: an Australian perspective. In: BLAIR, R.J., SAS, A.N., HAYS, P.F. \& HØJ, P.B. (eds). Proceedings of the $10^{\text {th }}$ Australian Wine Industry Technical Conference. pp. 158-159.

SOELLICK, T.R., UHRIG, J.F., BUCHER, G.L., KELLMANN, J.W. \& SCHREIER, P.H., 2000. The movement protein NSm of tomato spotted wilt tospovirus (TSWV): RNA binding, interaction with the TSWVN protein, and identification of interacting plant proteins. Proc. Natl. Acad. Sci. USA 97, 2373 2378 .

SOMMER-KNUDSEN, J., BACIC, A. \& CLARKE, A.E., 1998. Hydroxyprolinerich plant glycoproteins. Phytochem. 47, 483-497.

SPARVOLI, F., MARTIN, C., SCIENZA, A., GAVAZZI, G. \& TONELLI, C., 1994. Cloning and molecular analysis of structural genes involved in flavonoid and stilbene synthesis in grape (Vitis vinifera L.). Plant Mol. Biol. 24, 743-755.

SPENCER, P.A., TANAKA, A. \& TOWERS, G.H.N., 1990. An Agrobacterium signal compound from grapevine cultivars. Phytochem. 29, 3785-3788.

SRINIVASAN, C. \& MULLINS, M.G., 1980. High frequency somatic embryo production from unfertilized ovules of grapes. Sci. Hort. 13, 245-252.

STAMP, J.A. \& MEREDITH, C.P., 1988a. Somatic embryogenesis from leaves and anthers of grapevine. Sci. Hort. 35, 235-250.

STAMP, J.A. \& MEREDITH, C.P., 1988b. Proliferative somatic embryogenesis from zygotic embryos of grapevine. J. Am. Soc. Hort. Sci. 113, 941-945.

STAVRAKAKIS, M.N. \& BINIARI, K., 1998. Genetic study of grape cultivars belonging to the muscat family by random amplified polymorphic DNA markers. Vitis 37, 119-122.

STEVENSON, A.C., 1985. Studies in the vegetational history of S.W. Spain. II. Palynological investigations at Laguna de los Madres, Spain. J. Biogeorgr. 12, 293-314.

STOTZ, H.U., CONTOS, J.J.A., POWELL, A.L.T., BENNET, A.B. \& LABAVITCH, J.M., 1994. Structure and expression of an inhibitor of fungal polygalacturonase from tomato. Plant Mol. Biol. 25, 607-617.

TACKE, E., SALAMINI, F. \& ROHDE, W., 1996. Genetic engineering of potato for broad-spectrum protection against virus infection. Nat. Biotechnol. 14, 1159711601.

TERRAS, F., SCHOOFS, H., DE BOLLE, M., VAN LEUVEN, F., REES, S., VANDERLEYDEN, J., CAMMUE, B. \& BROEKAERT, W., 1991. Analysis of two novel classes of plant antifungal proteins from radish (Raphanus sativus L.) seeds. J. Biol. Chem. 267, 15301-15309.
THIS, P., CUISSET, C. \& BOURSIQUOT, J.M., 1996. Development of molecular markers in grapevine based on RAPD. Riv. Vitic. Enol. 49, 69-70.

THIS, P., CUISSET, C. \& BOURSIQUOT, J.M., 1997. Development of stable RAPD markers for the identification of grapevine rootstocks and the analysis of genetic relationships. Am. J. Enol. Vitic. 48, 492-501.

THOMAS, M.R., CAIN, P \& SCOTT, N.S., 1994. DNA typing of grapevines: A universal methodology and database for describing cultivars and evaluating genetic relatedness. Plant Mol. Biol. 25, 939-949.

THOMAS, R.M., CAIN, P., SCOTT, N.S., COLLINS, G.G. \& SYMONS, H.R., 1996. Differentiation and identification of grapevine cultivars by DNA typing. Riv. Vitic. Enol. 49, 57-58.

TOMASHOW, M.F., PANAGOPOULOS, C.G., GORDON, M.P. \& NESTER, E.W., 1980. Host range of Agrobacterium tumefaciens is determined by the Tiplasmid. Nature 283, 794-796.

TORREGROSA, L., PÉROS, J.P., LOPEZ, G. \& BOUQUET, A., 2000. Effect of hygromycin, kanamycin and phosphinothricin on the embryogenic callus development and axillary micropropagation of Vitis vinifera L. In: BOUQUET, A. \& BOURSIQUOT, J.M. (eds). Proceedings of the International Symposium on Grapevine Genetics and Breeding, ISHS, vol. I, Acta Hort. 528, 401-403.

VIDAL, J.R., MORENO, S., GOGORCENA, Y., MASA, A. \& ORTIZ, J.M., 1999. On the genetic relationships and origins of six grape cultivars of Galicia (Spain) using RAPD markers. Am. J. Enol. Vitic. 50, 69-75.

VIVIER, M.A., BECKER, J., CARSTENS, M., DE ASCENSAO, A., DE BEER, A., MARAIS, E. \& PRETORIUS, I.S., 2000. Engineering fungal resistance in grapevine (Vitis vinifera). $6^{\text {th }}$ International Symposium on Grapevine Physiology and Biotechnology, Greece.

WACKETT, L.P., 2000. Environmental biotechnology. TIBTECH 18, 19-21.

WALKER, M.A. \& BOURSIQUOT, J.M., 1992. Ampelographic and isozyme data correcting the misnaming of the grape rootstock $\mathrm{SO} 4$ at the University of California, Davis. Am. J. Enol. Vitic. 43, 261-265.

WALTER, B., 2000. Genetically modified grapes and their denomination. IWLA Bull. 21, 12-18.

WALTER, B. \& MARTELLI, G.P., 1997. Clonal and sanitary selection of the grapevine. In: WALTER, B. (ed). Sanitary selection of the grapevine. Protocols for detection of viruses and virus-like diseases, vol. 86. Editions INRA, Paris. pp. 43-95.

XU, B., KRASTANOVA, S., LING, S.V., SEKIYA, M.E., ZHU, H.Y., PETROVIC, N., REID, C.L., VELASQUEZ, I.M., BURR, T.J. \& GONSALVES, D., 1997. Transformation of grapevine rootstocks containing genes from grapevine fanleaf virus and grapevine leafroll-associated closterovirus 2 and 3. $12^{\text {th }}$ Meeting ICVC, Lisbon.

YANAGI, M. \& YAMASATO, K., 1993. Phylogenetic analysis of the family Rhizobiaceae and related bacteria by sequencing of the 16S rRNA gene using PCR and a DNA sequencer. FEMS Microbiol. Lett. 107, 112-120.

YANOFSKY, M., LOWE, B., MONTOYA, A., RUBIN, R., KRUL, W., GORDON, M. \& NESTER, E., 1985. Molecular and genetic analysis of factors controlling host range in Agrobacterium tumefaciens. Mol. Gen. Genet. 201, 237-246. YAO, C., CONWAY, W.S., REN, R., SMITH, D., ROSS, G.S. \& SAMS, C.E., 1999. A gene encoding polygalacturonase inhibitor in apple fruit is developmentally regulated and activated by wounding and fungal infection. Plant Mol. Biol. 39, 1231-1241.

YE, G.N., SOYLEMEZOGLU, G., WEEDEN, N.F., LAMBOY, W.F., POOL, R.M. \& REISCH, B.I. 1998. Analysis of relationship between grapevine cultivars, sports and clones via DNA fingerprinting. Vitis 37, 33-38.

ZHU, Q., MAHER, E.A., MASOUD, S., DIXON, R.A., LAMB, C.J., 1994. Enhanced protection against fungal attack by constitutive co-expression of chitinase and glucanase genes in transgenic tobacco. BioTechnol. 12, 807-812. 